\title{
What Do Americans Want From (Private) Government? Experimental Evidence Demonstrates that Americans Want Workplace Democracy $^{*}$
}

\author{
Soumyajit Mazumder ${ }^{\dagger}$ Alan Yan ${ }^{\ddagger}$ \\ Date last updated: August 19, 2020
}

\begin{abstract}
Much of the American labor force spends time in "private governments" over which they have little say during and beyond the work day. Do Americans prefer to work for businesses that look more like democracies or autocracies? We study this question using conjoint experimental techniques on a nationally representative sample of Americans. This design allows us to vary a large number of features of the workplace-especially their governance structures and the degree to which these structures allow for meaningful democratic decision-making. We hypothesize that workers should have a preference for democratic corporate governance structures such as employee ownership, co-determination, and the direct election of management. We find strong support that Americans have a preference for workplace democratization and that the magnitude is economically significant. Overall, this article marshals new data and analyses to better understand public preferences over "corporate regime type."
\end{abstract}

\footnotetext{
${ }^{*}$ Any views expressed are those of the authors and not those of the authors' employers. We would like to thank Alex Hertel-Fernandez for helpful comments and discussions on early stages of the project. We also thank Eric Schickler, Paul Frymer, Jane Gingrich, Chris Havasy, Jaclyn Kaslovsky and participants of the summer workshop in American Political Economy for helpful advice and feedback. We also would like to thank John Ray and YouGov for assistance in fielding this study. We would like to thank the Harvard Digital Laboratory for Social Sciences for fielding a pilot study. Soumyajit Mazumder acknowledges support by the James M. and Cathleen D. Stone Ph.D. Scholar Fellowship from the Multidisciplinary Program in Inequality \& Social Policy at Harvard University. This work has been approved by the Harvard Institutional Review Board (IRB19-1289) and Princeton Institutional Review Board (IRB 12814). The experimental design was pre-registered under the American Economic Association's Randomized Control Trial Registry AEARCTR-0005777.

${ }^{\dagger}$ Department of Government, Harvard University

${ }^{\ddagger}$ Charles and Louise Travers Department of Political Science, University of California Berkeley
} 


\section{INTRODUCTION}

Markets, at their best, ostensibly should reflect a deeply democratic space where consumers and producers can express their preferences through exit, voice, or loyalty (Hirschman 1972). But even if we accept such an ideal, the nature of production through the modern firm exposes a democratic dilemma hinted at by economists such as Coase (1937, pg. 387): production within the modern firm is organized via dictatorial control. As philosopher Elizabeth Anderson notes, "There are no internal markets in the modern workplace. Indeed, the boundary of the firm is defined as the point at which markets end and authoritarian centralized planning and direction begin" (Anderson 2017, pp. 37-39). Ironically, the non-market way in which production is organized within the firm makes it look more like a "communist dictatorship" than a democracy. Even more, the racialized nature of the American underclass where Black, Indigenous, and People of Color are disproportionately in precarious labor market conditions suggests that modern corporate governance might not only be dictatorships, but also resemble racial dictatorships (Robinson 2000; Du Bois 2014; Dippel 2014; Baradaran 2017; Taylor 2019). ${ }^{1}$ This elucidates the core research question we seek to understand: do businesses tend to have little resemblance to democracies because workers simply prefer not to work at firms that may ask of them to be democratic citizens on-the-clock?

These more abstract concepts have also been distilled into concrete proposals. For instance in 2019, Senator Tammy Baldwin (D-WI) sponsored the Reward Work Act, which proposed to mandate that large companies reserve a third of corporate board seats to be held by elected employees (co-determination). ${ }^{2}$ This idea also made it onto the campaign platforms of major Democratic Party presidential primary candidates such as Elizabeth Warren and Bernie Sanders. Though other forms of firms such as co-operatives do currently exist, they form a very small portion of the total employed labor force ( $<7000$ workers) today. ${ }^{3}$ Other types of firms that redistribute profits through Employee Stock Ownership Programs (ESOPs), though more significant $\left(\approx 10 \%\right.$ of the workforce), still are nowhere near the norm. ${ }^{4}$

\footnotetext{
${ }^{1}$ Even more, Leong (2013) documents how firms often times use minorities to boost their appeal to the general public without redistributing profits to the individuals whose identities have been commodified. Though the relationship between race and capitalism is a topic of renewed interest in social science (Combahee River Collective 1977; James 1989; Robinson 2000; Gilmore 2007; Du Bois 2014), it is not the direct object of study in this paper. Instead, racial capitalism provides the underlying context for understanding the nature of power and oppression in labor markets.

${ }^{2}$ See https://www.baldwin.senate.gov/press-releases/reward-work-act.

${ }^{3}$ See https://institute.app.box.com/s/5v7tnxs7afh65kghyv3hqfro1nrqpkd4. The Democracy at Work Institute estimates in their 2019 report that there are about 465 known worker co-ops employing 6,454 workers around the U.S. and Puerto Rico.

${ }^{4}$ This figures are according to figure put out by the National Center for Employee Ownership as of 2016. See
} 
While one might suggest that these sorts of firms that make power distribution more equitable among workers and management might generate efficiency costs, existing evidence suggests that, if anything, more democratically structured firms are often times more productive than their less democratic counter-parts (Blasi, Freeman, and Kruse 2014; Jager, Schoefer, and Heining 2019). If these firms are not less efficient than their less democratic counterparts (private corporations for instance), then is it the case that we don't observe workplace democratization because Americans simply don't want to work at these types of firms?

We study this question by fielding a pre-registered conjoint experimental task on a nationally representative sample that elicits underlying preferences for different types of workplaces. Our experimental design, commonly used in the marketing literature and increasingly in political science, has the advantage of randomly varying a large array of attributes of these hypothetical firms. ${ }^{5}$ Particularly to study preferences toward democratic corporate governance institutions, we randomly vary the presence of various policies such as employee ownership (commonly known as Employee Stock Ownership Plans or ESOPs), co-determination, and the direct election of management by employees. One risk of experimental designs is that they suffer from compound treatment effects or prime other factors that generate post-treatment bias. Because our design allows us to also randomly vary features such as salary, benefits, and work times-factors that respondents also might anticipate changing if they were in more democratic workplaces, we are able to decouple the intrinsic preferences of workplace democracy from its material benefits. In addition to ascertaining the marginal effect of such policies on labor supply at the extensive margin, we also ask respondents a series of questions probing why they prefer various types of working conditions and how they evaluate trade-offs. While we do not have the benefit of construct validity that would be provided by other designs such as field experiments, our design has the advantage of being able to isolate the intrinsic benefits of workplace democratization, measure additional outcomes beyond labor supply, and to benchmark our estimates against economic features such as salary and other labor organizations such as unionization.

Our experimental design allows us to isolate many features that would likely change as a result of economic democratization (salary, benefits, workplace culture, etc.) and recover intrinsic desires for economic democracy. We summarize the results of our experiment below:

https://www.nceo.org/articles/employee-ownership-by-the-numbers for further details.

${ }^{5}$ While we note that real world job searches are often made in much more constrained ways in which many of these features are hidden to those on the job search, our design allows us to understand unconstrained preferences in ways that allow us to overcome issues of information equivalence in experimental designs (Dafoe, Zhang, and Caughey 2018). 
1. Respondents want to work at democratically organized firms: Our results show that respondents are more likely to prefer to work at firms with workers on their corporate board, employee ownership programs, and direct election of management by 7,10 , and 4 percentage points respectively. Thus, we demonstrate that the lack of economic democracy is not because workers don't prefer to work at these types of firms.

2. Preferences for workplace democracy are economically meaningful: We estimate that respondents value economic democracy equivalently to a wage increase of approximately $\$ 20$ hour. $^{6}$

3. Respondents prefer to work at democratic firms in part because they intrinsically value having more power at work: Our experimental design also allows us to hold many other job search factors constant such as salary, benefits, and workplace culturefeatures that would also likely change in response to workplace democratization. As a result, we are able to isolate that individuals value workplace democracy because they perceive that they would have more power at the workplace. Labor republican theorists argue that workers should want more democratic power at work and we find that they do.

4. We find little partisan polarization around workplace democracy: Despite the spillover of partisan polarization into many areas such as hiring (Iyengar and Westwood 2015), dating (Huber and Malhotra 2016), and perceptions of people (Ahler and Sood 2018; Mason 2018), we show that there is little evidence of partisan polarization around workplace democratization. We do find, however, some evidence that Republicans have a slight preference against co-determination despite recognizing that they would have more power in the workplace as a result of co-determination.

5. Americans do not exhibit a strong preference to work at union shops: While unions have traditionally been one way to bring more democratic decision-making to the workplace through collective bargaining, we find that Americans actually have a slight preference against union shops (largely driven by Republicans). One reason for this is that Americans are not substantially more likely to view unions as providing them with more power on average.

\footnotetext{
${ }^{6}$ While this might be an upper bound on the true wage equivalence, imply similarly low labor supply elasticities (Dube et al. 2020).
} 
This project contributes to and extends several streams of literature in the political economy of the workplace. Broadly, our project extends existing work in economics and management that focus on preferences for types of work along economic dimensions such as compensation, flexibility, and benefits (Kostiuk 1990; Frymer 2005; Freeman and Rogers 2006; Eriksson and Kristensen 2014; Flory, Leibbrandt, and List 2015; Mas and Pallais 2017; Beglo and Gorges 2018; Wiswall and Zafar 2018). Building on work by Freeman and Rogers (2006) and Kochan et al. (2019), we argue that workers not only have preferences over the economic fundamentals of labor arrangements, but also the political fundamentals over the supply of labor (Dahl 1986; Gourevitch 2014; Anderson 2017; Eidlin and Uetricht 2018). This implies that studies of labor supply and job search overlook an important dimension of work. We improve over related work by Freeman and Rogers (2006), by using a conjoint experimental design where we are able to elicit preferences over the political arrangements of work and compare them to preferences over economic arrangements holding all else equal. While our study most closely relates to recent work by Hertel-Fernandez, Kimball, and Kochan (2019) who focus on preferences over union arrangements and collective bargaining, we complement this work by highlighting how alternative governance arrangements shape the types of firms Americans want to work at.

This project also contributes to literatures in political theory, corporate governance, and business ethics. While these issues are core areas of inquiry in the other social sciences such as sociology and economics, mainstream political science for the most part has been relatively silent on these issues. ${ }^{7}$ Normative theorists and activists in the republican tradition argue that workers should want workplace democracy because it appropriately checks the power of employers by employees (Gourevitch 2014; Anderson 2017). By designing the experiment in a way that separates intrinsic preferences from instrumental preferences, we find some credence to the labor republican claim that workers desire a more equitable distribution of power among employees, managers, and executives within the firm. While existing conceptualizations of corporate governance focus on the role of contracting (Alchian and Demsetz 1972)

\footnotetext{
${ }^{7}$ For sociological work, see Fligstein (1993), Davis and Thompson (1994), Davis and Greve (1997), Kang and Sorenson (1999), and Goldstein (2012). For economics work, see Hart and Moore (1990), Rajan and Zingales (1998), La Porta, Lopez-de-Silanes, and Shleifer (1999), La Porta et al. (2000), Rajan and Zingales (2002), Gompers, Ishii, and Metrick (2003), Pagano and Volpin (2005), Blasi, Freeman, and Kruse (2014), Azar, Schmalz, and Tecu (2018), Jager, Schoefer, and Heining (2019), and Ederer, Cunningham, and Ma (Forthcoming). For an exception to this in political science, see Cioffi and Hopner (2006), Ciepley (2013, 2017), Hertel-Fernandez (2018), and Hertel-Fernandez, Kimball, and Kochan (2019) for instance. This work, however, fails to find itself into mainstream political science. Despite the importance of corporations in the American economy, only four articles in the American Political Science Review in the past ten years make any mention to corporations for example.
} 
and shareholder democracy (Bebchuk 2005), both conceptualizations fundamentally neglect the role of everyday workers in firm governance. The reason for this neglect is that existing conceptualizations fail to recognize empirical facts such as labor market monopsony (Ashenfelter, Farber, and Ransom 2010; Azar, Marinescu, and Steinbaum, Forthcoming) and perhaps even structural coercion/domination (Gourevitch 2018) that undermines the interpretation that the relationship between employees and employers is fundamentally free. Taking this into consideration, theorists across many traditions argue for governance structures that give workers an actual seat at the table (Dahl 1986; Wright 2010; Anderson 2017). We find revealed preference evidence that workers tend to agree.

While existing research in political economy focuses on the relationship between labor and business as they relate to the state (Przeworski and Wallerstein 1988; Vogel 1989; Fligstein 1993; Wright 2000; Hall and Soskice 2001; Hertel-Fernandez 2019), we join empirical (Hertel-Fernandez 2018; Li 2018) and normative scholars (Gourevitch 2014; Anderson 2017; Gourevitch 2018) in urging scholars to broaden their notion of politics much in the spirit of seminal political scientists like Robert Dahl and refocus the lens of political scientists to better understand the politics of ostensibly non-political spaces. At its core, the study of politics is the study of power (Bachrach and Baratz 1962; Lukes 1974; Dahl 2005); as such, we show that Americans want more power shared more equitably at work.

\section{WORKPLACE DEMOCRATIZATION AND ITS PREMISES: THE VIEW}

\section{FROM THE LABOR REPUBLICAN TRADITION}

In this section, we provide a brief overview of existing understandings of the organization of the firm. We then move onto describe justifications for alternative firm organizations that distribute power in more equitable ways. Finally, we distill our hypotheses around worker preferences for economic democracy based on these two understandings of the firm.

Before outlining our theoretical expectations, it is important to clarify what exactly we mean by "the firm." Coase (1937)[pg. 393] writes, "A firm, therefore, consists of the system of relationships which comes into existence when the direction of resources is based on the entrepreneur." What sets the firm apart from individuals in a market place, then, is the nature of relationships between actors and (but not necessarily as discussed below) the entrepreneur. Firms, then, are inherently relational organizations of production that Coase (1937) notes lies outside of the price mechanism. Importantly, even Coase (1937) concedes that firms are dicta-

torial in the sense that entrepreneurs use their power to command their employees to produce 
a certain amount of goods. This Coasian theory of the firm characterizes the entrepreneur as having property rights over the residual labor of their employees (Grossman and Hart 1986; Hart and Moore 1990).

In contrast to Coase (1937), more conventional theories of the firm maintain that the firm is fundamentally a "team" of relationships to coordinate the translation of inputs into outputs (Alchian and Demsetz 1972). Rather than some exercise in dictatorial power, modern views of the firm see it as a set of free, contractual relationships between employees, managers, and entrepreneurs/owners (Alchian and Demsetz 1972; Rajan and Zingales 1998, 2002). This contractarian view of the firm rests on the fundamental argument that firms form rationally as a way to organize production efficiently in the face of transaction costs in the marketplace. Firms in this view are still fundamentally relationships of production, but where employees rationally and voluntarily enter into contracts that specify the terms of employment. In other words, this view posits that individuals rationally submit themselves to hierarchical authority in the workplace in the hopes that the employment contract will serve as an economic magna carta to check the arbitrary power of the king (management/ownership).

Modern theories of corporate governance now tend to emphasize shareholder value and the primacy of shareholder democracy (Berle and Means 1932; Jensen and Meckling 1976; Bebchuk 2005). These theories rightly diagnose the potential for rent-seeking behavior by managers and executives, but instead prescribe a solution where the goal of the corporation is to maximize shareholder value. While this might help to mitigate agency problems that generate rent-seeking behavior by executives, recent evidence on the rise of institutional investors owning shares in multiple companies (also known as the common ownership hypothesis) demonstrates that concentration in investing generates anti-competitive practices within firms (Azar, Schmalz, and Tecu 2018). This generates situations where shareholders, who are becoming increasingly concentrated (Braun), themselves engage in rent-seeking behavior at the detriment of long-term firm value. But the shareholder democracy goal, even when operating at its ideal, fundamentally assumes that employees enter into employment relationships from a position of freedom.

Several empirical features of the actual workplace should disabuse the notion that modern or even historical employment relationships within the firm are or have been necessarily free. First, economists have extensively documented that the concentration of employers (monopsony) limits the ability of workers to leave firms thereby reducing their bargaining power when it comes to wages or benefits and that this has become increasingly important over time (Manning 2003; Ashenfelter, Farber, and Ransom 2010; Benmelech, Bergman, and Kim 2018; Autor 
et al. 2019; Azar, Marinescu, and Steinbaum, Forthcoming; Dube et al. 2020). While there is some "natural" tendency for labor market monopsony as a result of job search frictions, the evidence also suggests that forces such as trade policy (Benmelech, Bergman, and Kim 2018), "superstar" firms (Autor et al. 2019), and the rise of legal arrangement such as non-competes (Marx 2011; Krueger and Ashenfelter 2018; Balasubramanian et al., Forthcoming; Lipsitz and Starr, Forthcoming; Starr, Prescott, and Bishara, Forthcoming) have generated labor market concentration thereby tilting bargaining power away from workers and toward employers.

Labor market monopsony is not the only force shaping the balance of power between workers and their employers. Labor coercion, where workers are compelled to provide their labor, has historically taken the form of being quite violent and racialized (Chwe 1990; Naidu 2010; Acemoglu and Wolitzky 2011). Though it rarely takes on such violent forms through slavery, lynching, or police prosecution, modern day labor coercion still exists in significant ways. For instance, one estimate suggests that the total value of wage theft-where minimum wage workers are paid below minimum wage-exceeds the value of all property theft in the United States (Meixell and Eisenbrey 2014). More subtly, Hertel-Fernandez (2018) documents how employers use a combination of their coercive power to fire workers and modern surveillance techniques to pressure their employees to engage in political actions that might run counter to their own political beliefs.

Many structural features of the American economy also makes coercion a near endemic feature of labor markets. Because of the way in which social policy, most notably health insurance, has been privatized and tied to employment (Hacker 2004), workers with employerprovided health insurance are forced to choose between their health and their freedom to leave. Other scholars such as Gourevitch (2018) argue that this issue between the freedom to leave and choosing one's livelihood is in fact a defining feature of modern capitalist economies. Because workers without independent sources of wealth, which consists of the vast majority of workers, must work to survive, any participation in labor markets in a capitalist economy is fundamentally coercive. Thus while the contractarian vision of the modern firm presumes that contracts are made under fundamentally free conditions between employers and employees, the nature of wealth distribution today implies that such a decision to even engage in work at all is a product of coercion.

These forces, consisting of the rising power of firms in dictating labor conditions to workers and the subtle or even pervasive nature of labor coercion in capitalist economies, suggest that most workers actually work in fundamentally unfree conditions. In other words as Anderson (2017) argues, most Americans spend most of their time in dictatorships. This critique, 
though recently re-articulated by Anderson (2017), goes far back in American intellectual history to the Jeffersonian vision of the ideal "yeoman" farmer and artisan and into the 19th and early 20th century with the union and co-operative movement (Blasi, Freeman, and Kruse 2014; Gourevitch 2014).

This critique of the fundamentally undemocratic nature of the modern firm revolves around neorepublican political theorist's concept of domination (Pettit 1999; Anderson 2017). ${ }^{8}$ Lovett and Pettit (2009)[pg. 14] characterize non-domination as follows:

I dominate you in a particular choice to the extent that I have the capacity, not subject to your direct or indirect check, to interfere in the choice, and I can employ that capacity to make it more probable, defiance apart, that you will choose to my pleasure or taste. I may employ my capacity in any of at least three ways:

1. I may exercise the capacity in active interference, trying to push you in my desired direction.

2. I may hold the capacity in reserve against the possibility that you are not disposed to go in the direction I prefer. That is, I may "invigilate" or monitor your choice for that possibility but allow you otherwise to choose as you are inclined.

3. I may make a display of the capacity, thereby intimidating you into making preemptive adjustments in my favor. For example, you may censor your choice so that it conforms to my taste.

Employed in any of these ways, the unchecked capacity to interfere will give me a degree of arbitrary control over your choice.

For neorepublican theorists, then, domination left unchecked by one group over another implies that the relationship is unfree. Anderson (2017) building on the labor republican tradition (Gourevitch 2014) extends this logic to employment relationships. Essentially, workers absent to check the power managers and employers exist in an unfree relationship of domination under the republican logic. To compensate for this unfreedom, republican theorists

\footnotetext{
${ }^{8}$ Robert Dahl similarly critiques the nature of the firm, but from the perspective of a distributive democratic framework (Dahl 1986). Essentially, Dahl makes a Kantian argument that because humans are fundamentally equal, they deserve equal claims over decisions in the firm. While we do not take up this logic of workplace democracy in much detail in this article, this claim is testable within the empirical framework outlined in this article.
} 
argue that those in a dominated relationship must be able to check the power of the dominating group through electoral mechanisms, veto power, etc. Applying this logic to the firm, Anderson (2017) concludes that truly free employment relationships require workers to have some sort of check on the power of managers. ${ }^{9}$

Figures 1 and 2 visually represent the power logic within firms in positions of domination (autocracy) or non-domination (democracy). In Figure 1, which represents the modern corporation, we visualize how ultimate power flows from the employer to the employees. This schematic captures the power imbalance where employers and managers have strong power over employees with employees having little power over management or employers. ${ }^{10}$

Alternatively, labor republicans argue that workers should be able to check the power of their superiors as shown in Figure 2. Many existing and newer proposals for economic democracy fall neatly within this framework. For instance, policies such as mandating employee representation on corporate boards (co-determination) allow workers to check the domination of employers by providing them with a direct source of voting power over high-level company policies and priorities. Other common forms of firm governance such as employee ownership/employee stock opportunity programs (ESOPs) directly give shares to employees. Through a principle of shareholder democracy, workers would have a vote equivalent to value of their shares thereby giving them a potential check against domination by the employer. Finally, one might even consider more radical policies such as the direct election of managers and executives by employees. This would provide a source of power against domination by employers by tying the fate of the manager's position to the democratic consent of employees. While these are of course not an exhaustive way in which scholars and activists propose to flatten workplace hierarchies, they do tap into basic principles of economic democracy.

While labor republicans argue that workers should want economic democratization, do workers actually want workplace democracy? If, as the contractarians argue, that the modern corporation is designed to maximize profits in the most efficient way and that this goal is in the best interest of everyday employees, then workers should be willing to give up working in a democracy to be able to reap these gains. ${ }^{11}$ For "standard" corporate governance theorists,

\footnotetext{
${ }^{9}$ One can also derive an alternative justification based on principles of distributive justice for workplace democracy via the principles laid out in Dahl (1986). Rather than require non-domination in the workplace, Dahl (1986) starts from the premise that if workers are fundamentally equal, then their workplaces must allow for equal voice by all members of the firm in decision-making. See Mayer (2001) for a critique of Dahl and Dahl (2001) for his response. Wright (2010) lays out yet another justification for workplace democracy rooted in Marxist theory.

${ }^{10}$ The problem of managers as an intermediate class has been debated elsewhere. For an introduction to theories of the professional-managerial class, see Ehrenreich and Ehrenreich (1979).

${ }^{11}$ The dominant view today is that modern corporations exist to maximize shareholder value, which allows
} 


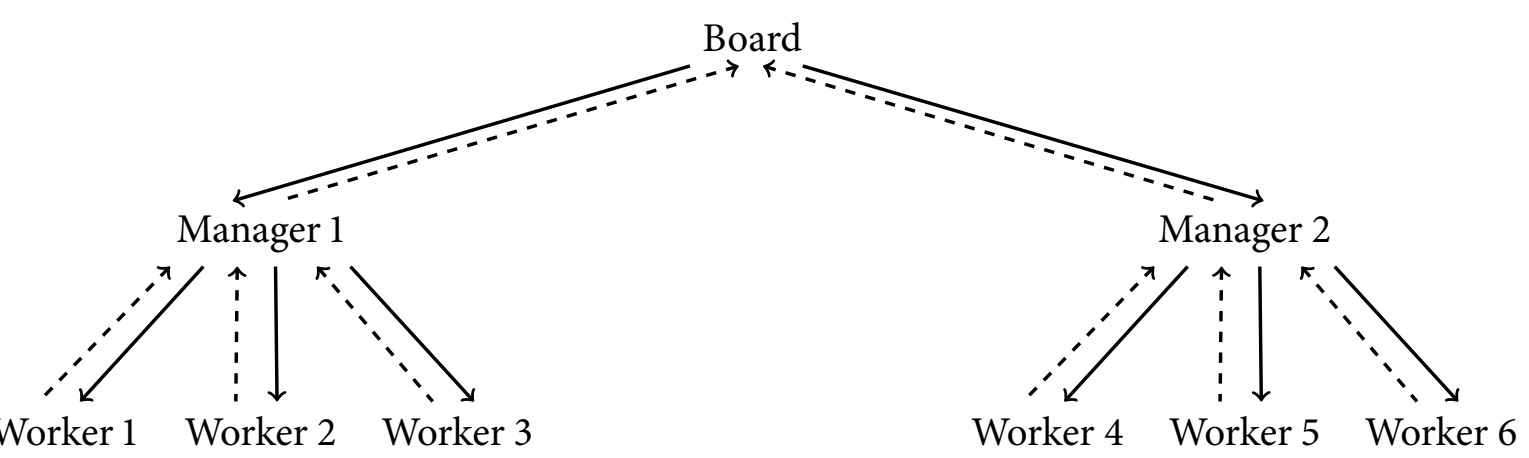

Figure 1: Autocratic workplace. Solid lines represent one person having great say over another person's job, while dashed lines represent one person having less say over another person's job.

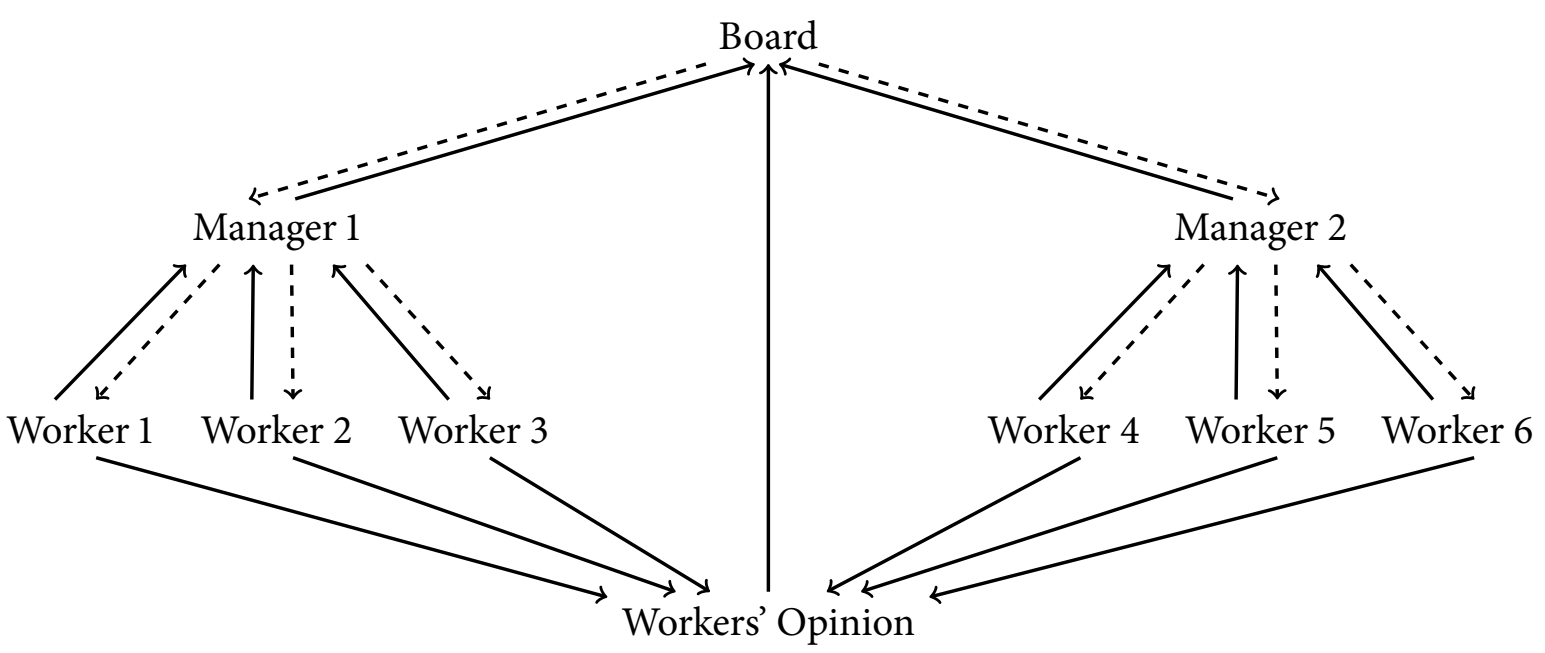

Figure 2: Democratic workplace. Solid lines represent one person having greater say over another person's job, while dashed lines represent one person having less say over another person's job. 
the answer is a clear no. Instead, as labor republicans argue, that the modern corporation is essentially an undemocratic body and that workers intrinsically value having power over decision making, then workers should have a preference for democratically organized firms where power distribution is equitable.

Thus, we distill the labor republican hypothesis as follows: If workers intrinsically value having power in the workplace, then they should be more willing to work at firms that are democratically governed relative to those that are not.

Alternatively, the contractarian thesis is: if workers are satisfied with the amount of power that they have in the workplace, then should should be less willing to work at firms that are democratically governed relative to those that are not.

\section{EXPERIMENTAL DESIGN}

In this section, we use a conjoint survey to attain a comprehensive sense for Americans' preferences toward the workplace. While perhaps an "ideal" experiment would be to randomize real-world job advertisements, this field experimental approach would be unable to disentangle intrinsic preferences for economic democracy as theorized by labor republicans from more instrumental ones since it would require us to randomize a large number of potentially confounding factors to isolate intrinsic preferences from instrumental ones. ${ }^{12}$ Particularly, we design our experiment specifically to test the republican proposition that workers not only should want workplace democracy, but that they actually do want it. Conjoint designs are an increasingly popular measurement tool in political science (Hainmueller, Hopkins, and Yamamoto 2014; Hainmueller and Hopkins 2014; Bansak et al. 2018), and they have been shown to approximate real-world behavior (Hainmueller, Hangartner, and Yamamoto 2015). This design allows one to estimate the Average Marginal Component Effect (AMCE) of a given attribute relative to a baseline category. In other words, we are able to estimate the individual contribution of a given feature relative to some baseline feature averaging over all other feature combinations. As pointed out in recent work (Abramson, Kocak, and Magazzinik 2020; Abramson et al. 2020), the main drawback to conjoint designs and the AMCE estimand is

firms to solve agency issues where executives/managers may engage in rent-seeking behavior at the detriment of the firm.

${ }^{12}$ For instance, respondents may infer that firms with workplace democracy policies will have higher pay, benefits, and better working conditions. These instrumental benefits would be observationally equivalent to intrinsic benefits thereby inducing informational equivalence (Dafoe, Zhang, and Caughey 2018). Unfortunately, randomizing all of these potential factors would lead to power issues. Given the results of this study, we believe such a field experiment approach would be useful in further work. 
Figure 3: Example of Conjoint Profile

\begin{tabular}{|l|l|l|}
\hline & \multicolumn{1}{|c|}{ Transportation and warehouse Firm 3 } & Transportation and warehouse Firm 4 \\
\hline Hours of Work & 60 hours a week & 60 hours a week \\
\hline Racial Diversity Practices & All people of color owned & Majority people of color owned \\
\hline Type of Task & Largely repetitive work & Largely creative work \\
\hline Gender Diversity Practices & Majority-men owned & Majority-men owned \\
\hline Paid Sick Leave & No paid sick leave & No paid sick leave \\
\hline Parental Leave & No parental leave policy & No parental leave policy \\
\hline Retirement Matching & Matches 25\% of 401k contributions & Matches 75\% of 401k contributions \\
\hline Firm Size & 1,000 co-workers & 1,000 co-workers \\
\hline Health Insurance Contribution & Employers pays 50\% & Employers pays 50\% \\
\hline Work with Others & Mix of individual and team work & Mix of individual and team work \\
\hline Corporate Social Responsibility & Commitment to corporate social responsibility & No corporate social responsibility \\
\hline Corporate Governance Structure & Privately owned by one individual & Workers sit on the corporate board \\
\hline Workplace Conditions & Somewhat friendly and supportive & Generally unfriendly and unsupportive \\
\hline Work From Home & Cannot work from home & Cannot work from home \\
\hline Location & Located in your city & Located in your city \\
\hline Unionization & Unionized & Not unionized \\
\hline Job Training Program & Ex-felons training & Mentally-disabled training \\
\hline Firm's Political Contributions & Donates to both Democrats and Republicans & Donates to both Democrats and Republicans \\
\hline
\end{tabular}

that it suffers from preference intensity issues where a positive AMCE might be drive by only a few observations who have a uniquely strong preference for that component. We address this issue directly by using machine learning techniques that are able to uncover underlying effect heterogeneity in valid ways (Athey, Tibshirani, and Wager 2020). To preview, we find minimal evidence that this preference intensity issue can explain our findings.

Our experiment places respondents in the position of a job seeker weighing different job offers. After introducing respondents to the task, we show respondents two firm profiles as displayed below in Figure 3. After reading the firm profiles, respondents answer five outcome measures. The first question forces respondents to indicate at which firm they would rather work. We code the responses to the question as a binary variable, Firm Preferred, which is 1 if the firm is preferred and 0 otherwise. This is our key dependent variable. This variable approximates the real labor market in that when someone accepts a job offer, they must reject the other offer. We then use two outcome variables to measure whether respondents believe that more democratic workplaces improve their day-to-day work experiences. We ask respondents which firm is "best at resolving any problems or complaints that arise at work" and at which firm they think "workers would have more power." Importantly, by measuring whether respondents believe that they have more power at one firm over another, we are able to under- 
stand the degree to which labor republican theories of freedom at work are driven by a desire for more equitable power distributions between employers and employees. Both measures are forced choice. Additionally, we ask respondents at which firm they think they would have more responsibilities to see whether workers realize that more democratic workplaces would require them to take on some managerial responsibilities.

Each respondent evaluates eight comparisons between pairs of firms, each displayed on a new page. We randomly vary the two firms' profiles of 19 attributes that one would might consider when choosing between job offers. The attributes include each firm's corporate governance, firm size, sick leave policy, health insurance, work hours, race of owners, gender of owners, corporate social responsibility commitment, parental leave policy, characterization of their work, retirement fund, relocation requirements, unionization, working conditions, specialized job training programs, work from home policy, political donations, and income offer. Each of these attributes could take on multiple values. For example, corporate governance, our main variable of interest, can take on the values: "Workers sit on the corporate board," "Workers elect their managers," "Workers are shareholders," "Privately owned by non-worker shareholders," "Publicly owned by shareholders," and "Privately owned by one individual." We randomly assigned the values for each attribute for each profile so that the two firms vary within and across comparisons. We also randomize the order in which attributes are listed to avoid primacy or recency effects. For all analyses, we set the baseline category to private ownership by non-worker shareholders since private corporations form the vast majority of American firms and employment. ${ }^{13}$ Tables 1 and 2 contain the full list of attribute values.

A conjoint survey can address several weaknesses that observational and other experimental designs face. First, because every attribute value is independently randomized, the design allows us to decouple attribute values that may be highly correlated in reality. For example, we can imagine that worker-friendly corporate governance may be correlated with higher pay, better benefits, and safer working conditions. This is critically important for understanding whether respondents have an intrinsic preference for workplace democracy rather than an instrumental preference. Second, the design allows us to compare the relative importance of each attribute. For example, we can directly compare respondents' preference for workplace democracy against their preferences for higher income. Finally, we can investigate whether some respondents prefer certain types of workplaces by interacting respondent and firm characteristics. Given the role of political partisanship in governing many features

\footnotetext{
${ }^{13}$ See https: //www. forbes. com/sites/sageworks/2013/05/26/4-things-you-dont-know-about-private-compa \#53adb400291a.
} 
Table 1: Conjoint Attributes and Levels

\begin{tabular}{l|l} 
Attributes & Values \\
Corporate Governance Structure & Workers sit on the corporate board \\
Workers elect their managers \\
Workers are shareholders \\
Firm Size & Privately owned by non-worker shareholders \\
Publicly owned by shareholders \\
Privately owned by one individual \\
50 co-workers \\
Paid Sick Leave & 50 co-workers \\
500 co-workers \\
Health Insurance Contribution & 5,000 co-workers \\
Hours of Work & No paid sick leave \\
Two weeks paid sick leave days \\
Unlimited paid sick leave days \\
Employers pays 50\% \\
Employers pays 75\% \\
Employers pays $100 \%$ \\
40 hours a week \\
50 hours a week \\
60 hours a week \\
70 hours a week \\
80 hours a week \\
All people of color owned \\
Majority people of color owned \\
Majority white owned \\
All White owned \\
Women owned \\
Majority-women owned \\
Majority-men owned \\
Men owned
\end{tabular}


Table 2: Conjoint Attributes and Levels

\begin{tabular}{|c|c|}
\hline Attributes & Values \\
\hline \multirow[t]{2}{*}{ Corporate Social Responsibility } & No corporate social responsibility \\
\hline & Commitment to corporate social responsibility \\
\hline \multirow[t]{2}{*}{ Parental Leave } & No parental leave policy \\
\hline & Generous parental leave policy \\
\hline \multirow[t]{3}{*}{ Type of Task } & Largely repetitive work \\
\hline & Mix of repetitive and creative work \\
\hline & Largely creative work \\
\hline \multirow[t]{3}{*}{ Work with Others } & Mostly working alone \\
\hline & Mix of individual and team work \\
\hline & Mostly team work \\
\hline \multirow[t]{5}{*}{ Retirement Matching } & Matches $100 \%$ of $401 \mathrm{k}$ contributions \\
\hline & Matches $75 \%$ of $401 \mathrm{k}$ contributions \\
\hline & Matches $50 \%$ of $401 \mathrm{k}$ contributions \\
\hline & Matches $25 \%$ of $401 \mathrm{k}$ contributions \\
\hline & Matches $0 \%$ of $401 \mathrm{k}$ contributions \\
\hline \multirow[t]{3}{*}{ Location } & Located in your city \\
\hline & Located in a different city \\
\hline & Located in a different city but pays for relocation \\
\hline \multirow[t]{2}{*}{ Unionization } & Unionized \\
\hline & Not unionized \\
\hline \multirow[t]{4}{*}{ Workplace Conditions } & Generally friendly and supportive \\
\hline & Somewhat friendly and supportive \\
\hline & Somewhat unfriendly and unsupportive \\
\hline & Generally unfriendly and unsupportive \\
\hline \multirow[t]{4}{*}{ Job Training Program } & Veterans training \\
\hline & Mentally-disabled training \\
\hline & Ex-felons training \\
\hline & No special job training program \\
\hline \multirow[t]{3}{*}{ Work from Home } & Primarily work from home \\
\hline & Sometimes work from home \\
\hline & Cannot work from home \\
\hline \multirow[t]{3}{*}{ Firm's Political Contributions } & Primarily donates to Democrats \\
\hline & Donates to both Democrats and Republicans \\
\hline & Primarily donates to Republicans \\
\hline Salary & $\$ 30,000$ to $\$ 300,000$ in $\$ 10,000$ increments \\
\hline
\end{tabular}


of contemporary American politics, we explore whether support for workplace democracy varies by partisanship and to what degree.

\section{Sample}

We fielded a nationally representative sample with YouGov Blue. YouGov is a high-quality sample used by academics and organizations that maintains a consistent panel of survey respondents on a wide variety of demographic attributes. Based on power calculations and our budget, we collected a sample of 1,002 respondents weighted to be nationally representative. Our total sample size is 8,016 respondent-trials. The survey was fielded the week of June 29th, 2020. We estimate all models using Ordinary Least Squares (OLS) with standard errors clustered at the respondent-level to account for correlation in errors within respondent. For simplicity and clarity of results presentation, we focus all estimates on the corporate governance conditions and report point estimates with 90 and 95\% confidence intervals.

\section{RESULTS}

Our core thesis is that workers should prefer corporate governance structures that make the firm more democratic with respect to its employees relative to structures that are less democratic. In this section, we present the results of our conjoint survey experiment showing that relative to the baseline condition of private ownership by non-worker shareholders (private corporations), respondents are more likely to prefer to work at places with more democratic workplaces and that they recognize that they would have more power at these firms. Because these results also randomize a wide array of other firm characteristics (such as salary, benefits, etc.), our results provide a lower bound for democratic workplace preferences since many democratic firms tend to also have better wages/salaries and benefits. Beyond our main effects, we use machine learning methods to better understand heterogeneity of our estimated effects and show that while both Democrats and Republicans tend to recognize that more democratic workplaces would give them more power, Republicans tend to be less likely than Democrats to prefer to work at firms with co-determination, but not ESOPs or managerelected firms. Thus while work preferences are politically polarized around proposals like co-determination that have received more media attention, other democratizing proposals do not yet exhibit such partisan polarization.

To begin our results presentation, we start by examining main effects of our workplace democracy treatments on whether respondents would prefer to work at such firms and whether 
Figure 4: Effect of different workplace regimes.

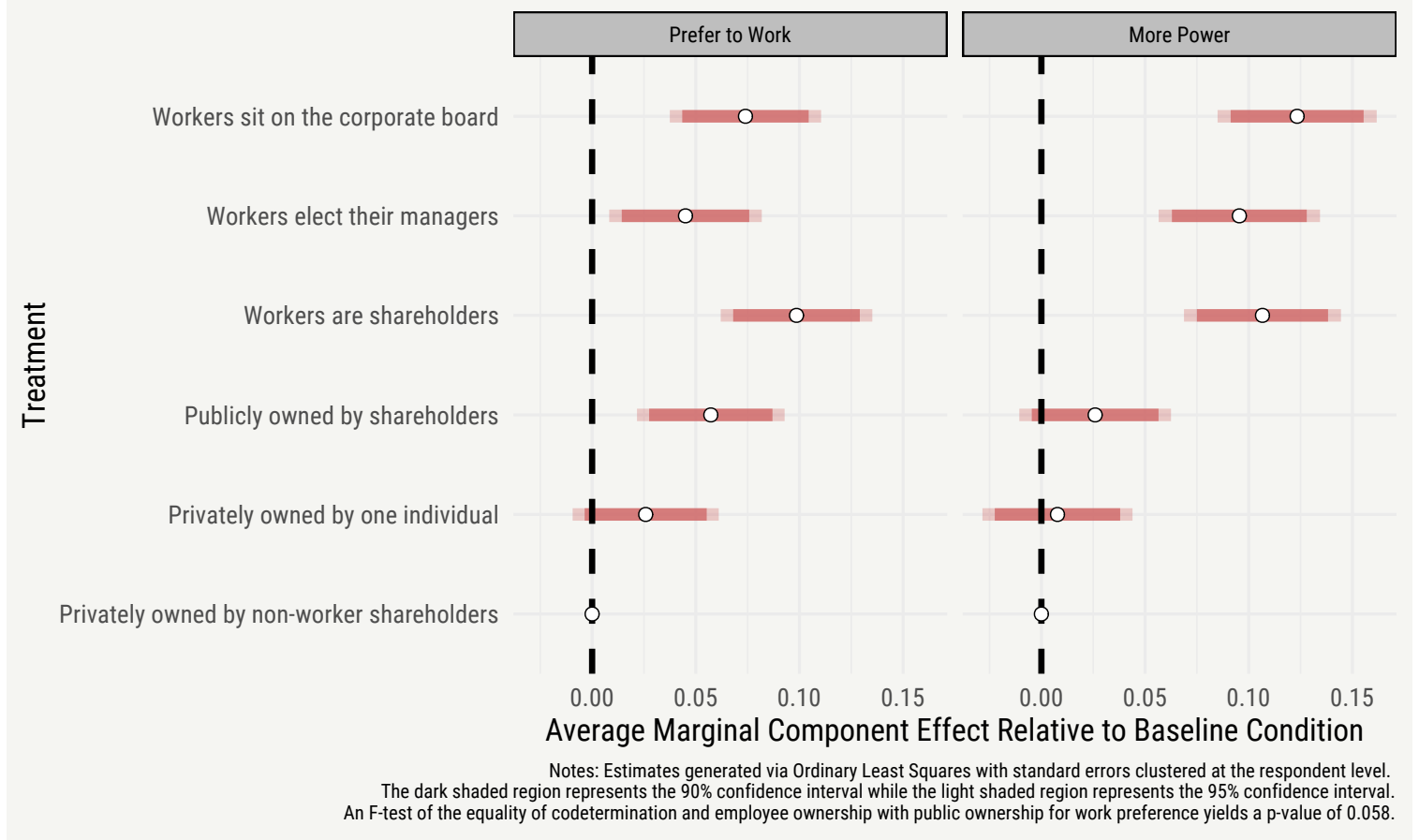

they recognize that they would have more power at such firms. Figure 4 plots the AMCE for each corporate governance proposal relative to the baseline of private ownership by nonworker shareholders (private corporations) for each outcome. We cluster all standard errors at the respondent-level and report 90 and 95\% confidence intervals (dark and light shaded regions respectively). In the left panel, we find that respondents in general prefer to work at more democratic workplaces to the private corporation. Relative to the baseline condition, co-determination raises the probability of preferring a given firm by 7 percentage points $\left(C I_{95}=[4 \mathrm{pp}, 11 \mathrm{pp}]\right)$, ESOP raises the probability of preferring a given firm by 10 percentage points $\left(C I_{95}=[6 \mathrm{pp}, 14 \mathrm{pp}]\right)$, and management elections raises the probability of preferring a given firm by 5 percentage points $\left(C I_{95}=[1 \mathrm{pp}, 8 \mathrm{pp}]\right)$. While respondents were also more likely to prefer public ownership by shareholders, the coefficients for ESOPs and co-determination are statistically distinguishable $\left(p_{\text {one-sided }}=0.03\right.$ and $\left.p_{\text {two-sided }}=0.06\right)$ from public ownership by shareholders. While we present unweighted estimates following our pre-analysis plan, we also report weighted estimates in Figure A1-1 in the Online Appendix and demonstrate that our conclusions remain unchanged. Our results suggest that the lack of more democratic workplaces is not because workers don't have a preference for 
them. $^{14}$

To provide a further sense of the economic magnitude, we directly benchmark our workplace democracy results with respect to salary offers. Because we also randomized salary offers in $\$ 10,000$ increments, we are essentially able to generate a labor supply curve based on salary. Using these estimates (see Figure A1-3 and Table A1-2 for details), we estimate that co-determination, ESOPs, and management elections are approximately equivalent to a $\$ 70,000, \$ 100,000$, and $\$ 40,000$ increase in salaries holding constant the implied utility that a respondent would get from working at a given hypothetical firm. This translates, on average, to approximately a $\$ 20 /$ hour increase in wages. This is likely an upper bound on the wage growth that individuals might be willing to forego so we caution against over-interpreting these magnitudes. Future work, using field experimental methods, are likely better suited to test for the actual wages that individuals might give up for workplace democracy. ${ }^{15}$ Nevertheless, our results suggest that workplace democracy preferences are economically meaningful. In short, respondents prefer to work at more democratic workplaces relative to private corporations and that the effect is substantively meaningful suggesting that the lack of workplace democracy in the United States is not because workers don't prefer economic democratization.

Causal Mechanism: Americans Prefer to Work in Democratic Workplaces Because They Intrinsically Value Having Power over Decision-Making

As we suggested before, our experimental design allows us to randomly vary a large number of potential features that job seekers might select on when applying to jobs. Because we randomize many features including salary, benefits, and the workplace culture of the firm, we are able to hold constant many features that would plausibly change as a result of economic democratization. This generates (1) a lower bound for the true job preference for workplace democracy and (2) an ability for us to isolate why individuals might support such policies. Using an additional item on whether respondents believe a given firm would provide them with more power relative to another one, we are able to also use our experimental design to elucidate whether respondents prefer workplace democracy precisely because it gives them more power over their economic lives. Our results, shown in the top right panel of Figure 4 demon-

\footnotetext{
${ }^{14} \mathrm{We}$ also find evidence of a preference for public corporations relative to private corporations. Our subsequent results on perceptions of power suggest that preferences for public corporations have less to do with power. Future work ought to do more to further explore public opinion around private and public corporations.

${ }^{15}$ Of course, data suggests that wages and workplace democracy are complements rather than substitutes. Our comparison holds constant total utility.
} 


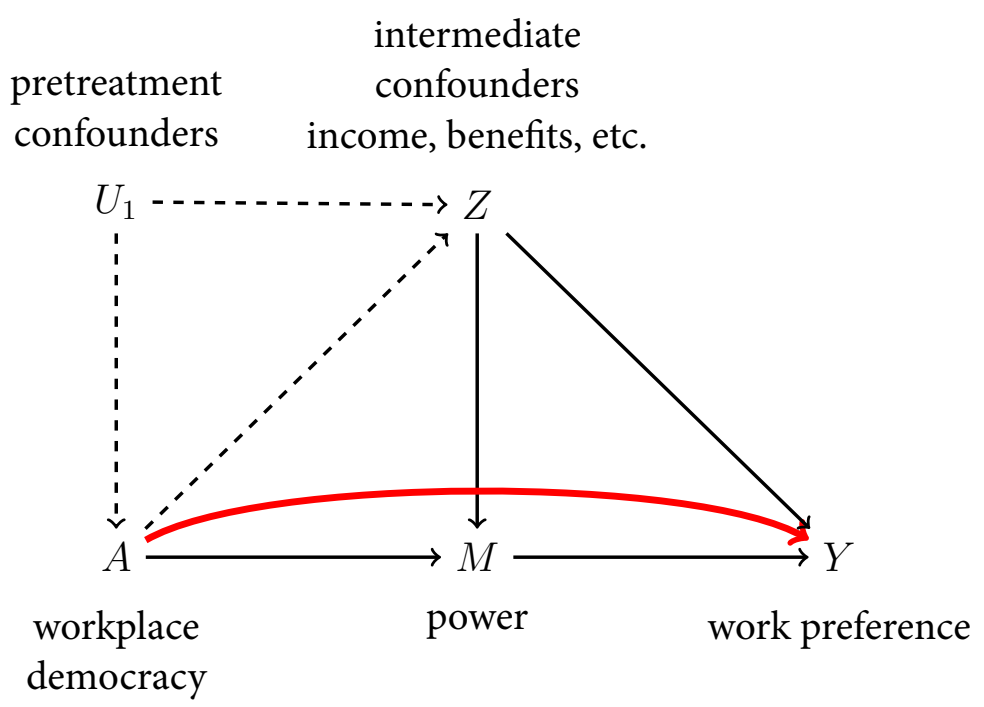

Figure 5: Directed Acyclic Graph of Identifying Assumption for Controlled Direct Effects

strate an even stronger effect of workplace democracy on the likelihood that a respondent perceives that they would have more power at the chosen firm. Across all co-determination, ESOPs, and management-elected firms, we find that individuals believe that they would have more power at these types of firms by about 10 percentage points across all proposals. In line with our proposed causal mechanism, we find evidence that workers believe that workplace democracy will bring them more power over their firm's decisions. Our results suggest that one reason why this preference for workplace democracy exists beyond the potential economic benefits is because workers have an intrinsic preference for having more control over their economic lives.

More formally, we conduct a mediation analysis with our identifying assumptions captured in Figure 5 to assess the degree to which intrinsic preferences for more power explain the relationship between workplace democracy and work preferences. Particularly, we aim to estimate the Average Controlled Direct Effect (ACDE) as well as the Average Natural Indirect Effect (ANIE) of each workplace democracy treatment on the outcome as way to assess whether there remains any direct effect of the treatment after accounting for its impact on perceptions of power (Acharya, Blackwell, and Sen 2016). ${ }^{16}$ Our experimental design allows us to recover

\footnotetext{
${ }^{16}$ The AMCE of each workplace democracy item can be decomposed into the ACDE, the ANIE, and an interaction between the treatment and the moderator. In the Figure A1-4 in the Online Appendix, we demonstrate that there is no significant effect moderation by power perceptions for co-determination and management elections thereby allowing us to estimate the ANIE for those treatments. We do find some evidence of effect modification for ESOPs and account for this in our estimates of the ANIE by re-centering as suggested by (Acharya,
} 
Figure 6: Mediation effect decomposition via the non-parametric bootstrap.

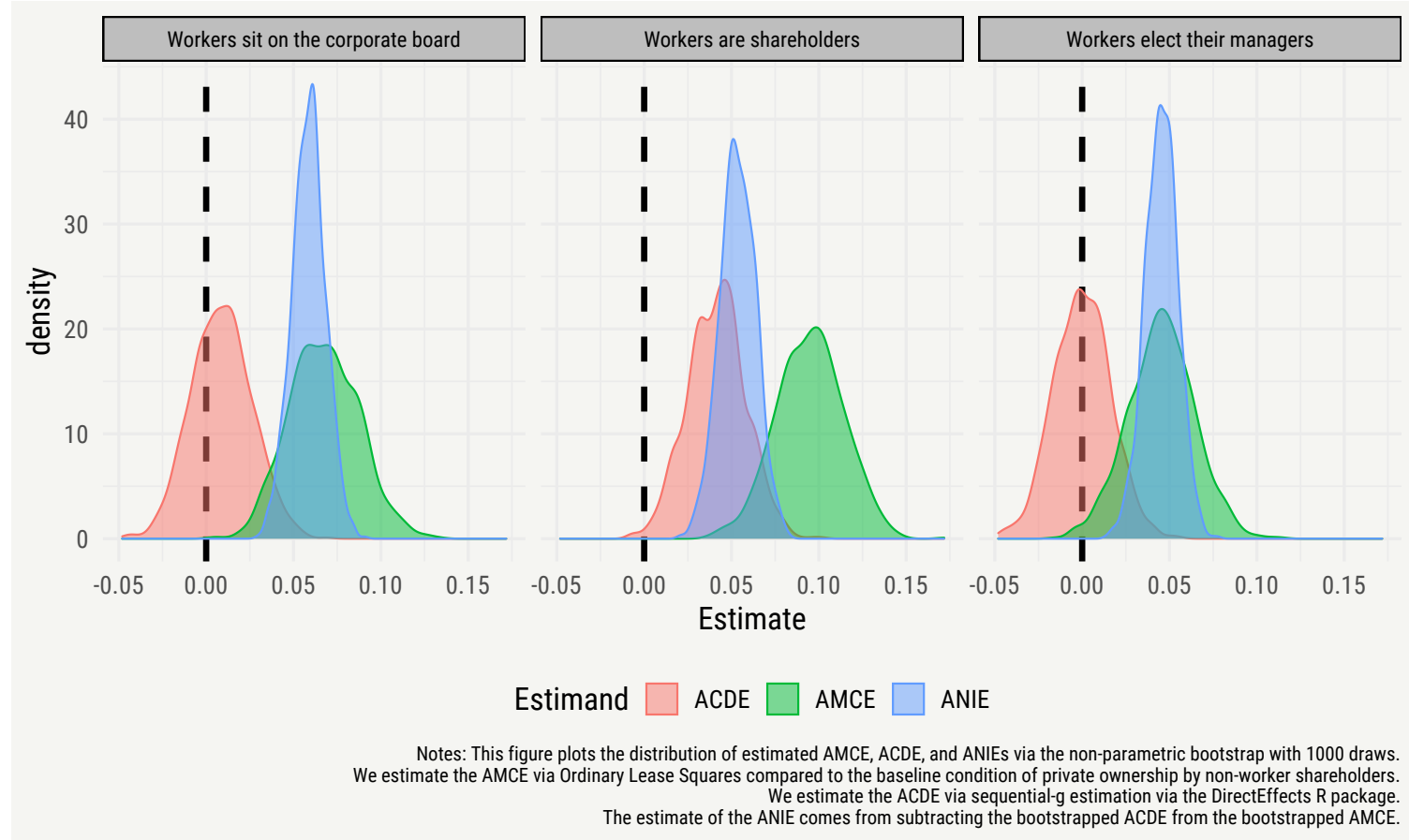

unbiased estimates of both the ACDE and ANIE (assuming no treatment-mediator interaction) by measuring and randomizing a wide set of potential $Z$ thereby making the sequential unconfoundedness assumption plausible in our setting.

We present distribution of bootstrapped ANIE and ACDE estimates in Figure 6. Overall, we find strong evidence suggesting that the causal of effect of workplace democracy is mediated through perceptions of increased power. Especially for co-determination and management elections, we find that their causal effects are almost completely mediated by increased perceptions of workplace power. For ESOPs, however, we do find that the effect is partially mediated by perceptions of power though not completely. While we do not have core hypotheses about the difference in mediation effects between these variables, we speculate that profit-sharing schemes through ESOPs are less directly connected to workers having power themselves. Future research would be warranted to disentangle how different workplace democracy proposals activate different types of motivations. In short, our results demonstrate strong evidence that the American public prefers workplace democracy because of the way in which it would increase their power at work. ${ }^{17}$

Blackwell, and Sen 2016).

${ }^{17}$ We also run sensitivity analyses of the sequential unconfoundedness assumption (see Figure A1-5 in the 
Partisan Polarization Does Not Govern Preferences for Workplace Democracy Yet, But it Has the Potential to Become Polarized

Partisans are polarized in almost all spaces today. Does this polarization also spillover into preferences over the workplace? To understand this, we use recently developed machine learning methods to uncover the underlying heterogeneity in our estimated causal effects. Particularly we use generalized random forests (GRF) developed by Athey, Tibshirani, and Wager (2020), which is an algorithm that finds subgroups with the maximal amount of difference between treated and control units. This algorithm iteratively partitions the covariate space to find these subgroups and uses multiple splits to generate "honest" confidence intervals that accurately reflect uncertainty from randomization and prediction. Once trained, the model allows us to make predictions about individual level causal effects (ie, what does the model predict the causal effect would be for a given respondent). In our context, we train the algorithm based on all pre-treatment covariates that we had access to including age, race, education, union status, partisanship, gender, and employment status. Not only does this exercise help us to understand heterogeneity in estimated causal effects, but it also allows us to uncover whether our results are driven by a few respondents who overwhelmingly prefer workplace democracy (Abramson, Kocak, and Magazzinik 2020; Abramson et al. 2020).

We present the results of this exercise in Figure 7 where each column presents a different comparison of a workplace democracy proposal against the baseline condition of private corporations and each row presents the estimate for a given outcome. We plot the estimate of the causal effect for a given trial and rank the trials by the estimated causal effect. Each shaded bar represents the 95\% confidence interval generated from the GRF algorithm. For reference, we also plot the estimated AMCE and its associated 95\% confidence interval represented by the solid black vertical line and shaded region. We shade each bar by whether the respondent identifies as a Democrat (blue), Independent (white), and Republican (red). We visually identify regions of polarization when the colors separate and regions of similarity when the shades intermix.

Focusing on the top row which presents the estimated causal effects on respondent's preferred workplace, Figure 7 provides evidence that individuals generally tend not to be very polarized by partisanship as it relates to work preferences and workplace democracy. For ESOPs and management elected firms, we find that Republicans are clustered around the overall AMCE suggesting whereas they are clustered at zero and below for co-determination. Worker

Online Appendix) and find that our results are robust to extremely large deviations from that identifying assumption. 
Figure 7: Effect of different workplace regimes.

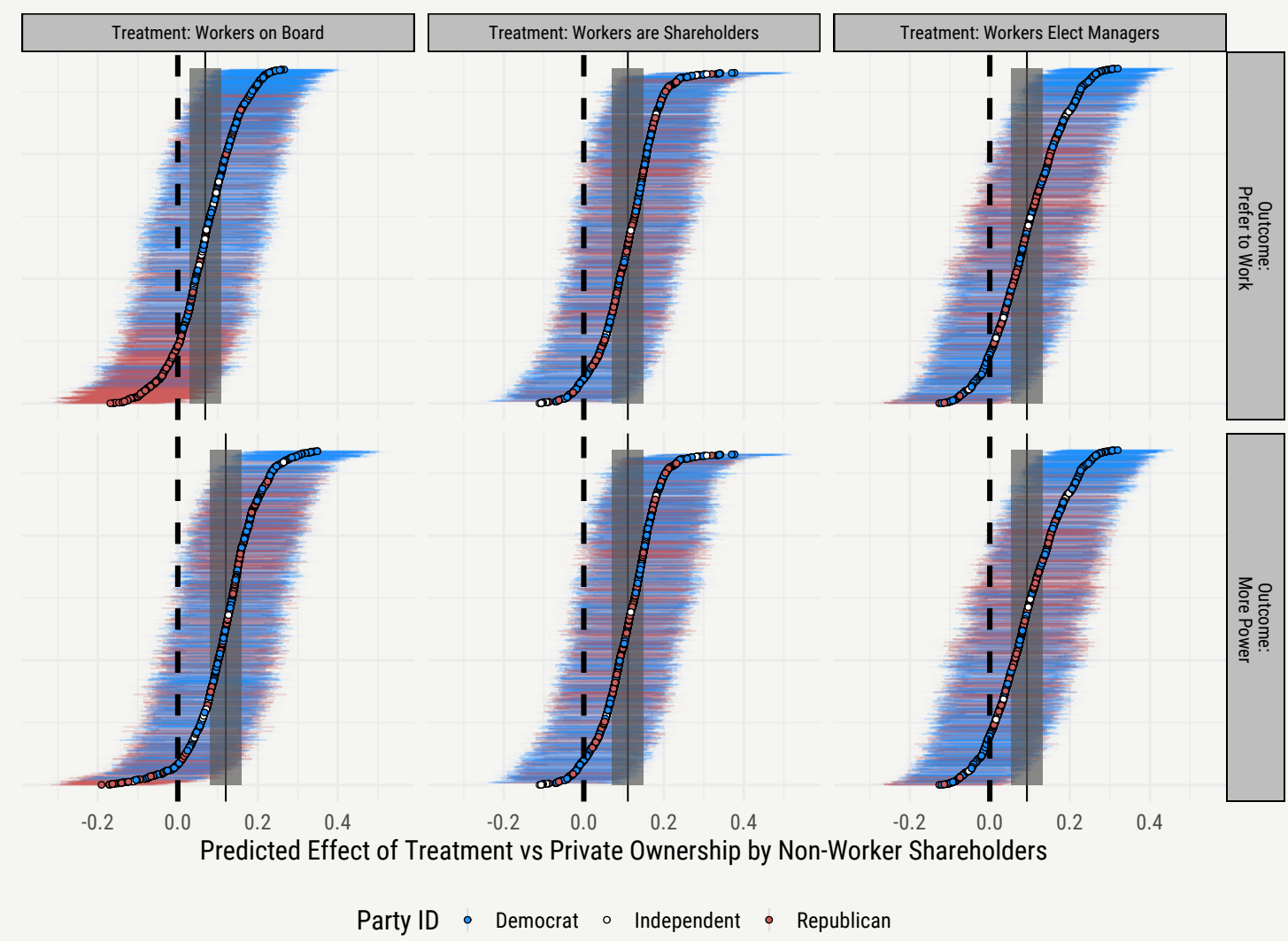

Notes: Estimates for the treatment effect for each trial where the comparison is against private ownership by non-worker shareholders are ranked by magnitude and generated via causal forests. The thin vertical line represent the estimated causal effect of each treatment with the vertical shaded regions representing the $95 \%$ confidence interval. The horizontal shaded regions represent $95 \%$ confidence intervals of individual level treatment effect estimates.

election of managers does seem to induce some asymmetric polarization where Democrats are clustered at the top of the ranked causal effects. Our interpretation of these results is that policies that have gotten less elite scrutiny (ESOPs and management elections), have not yet become polarized where instead policies like co-determination exhibit partisan polarization potentially because it has received more elite coverage. While our study is unable to answer why certain policies became polarized, future studies could use alternative designs to better understand the sources of polarization over this issue.

Do partisans (particularly Republicans) have a distaste for co-determination because they believe that they wouldn't actually have more power in the workplace? We find no evidence for this. The results in the bottom set of panels in Figure 7 demonstrates that partisans across the spectrum tend to agree that these workplace democracy proposals would actually give them more power. Instead these results suggest that for co-determination, Republicans recognize that they would have more power in the workplace, but that they might not intrinsically value 
Figure 8: Effect of unionization.

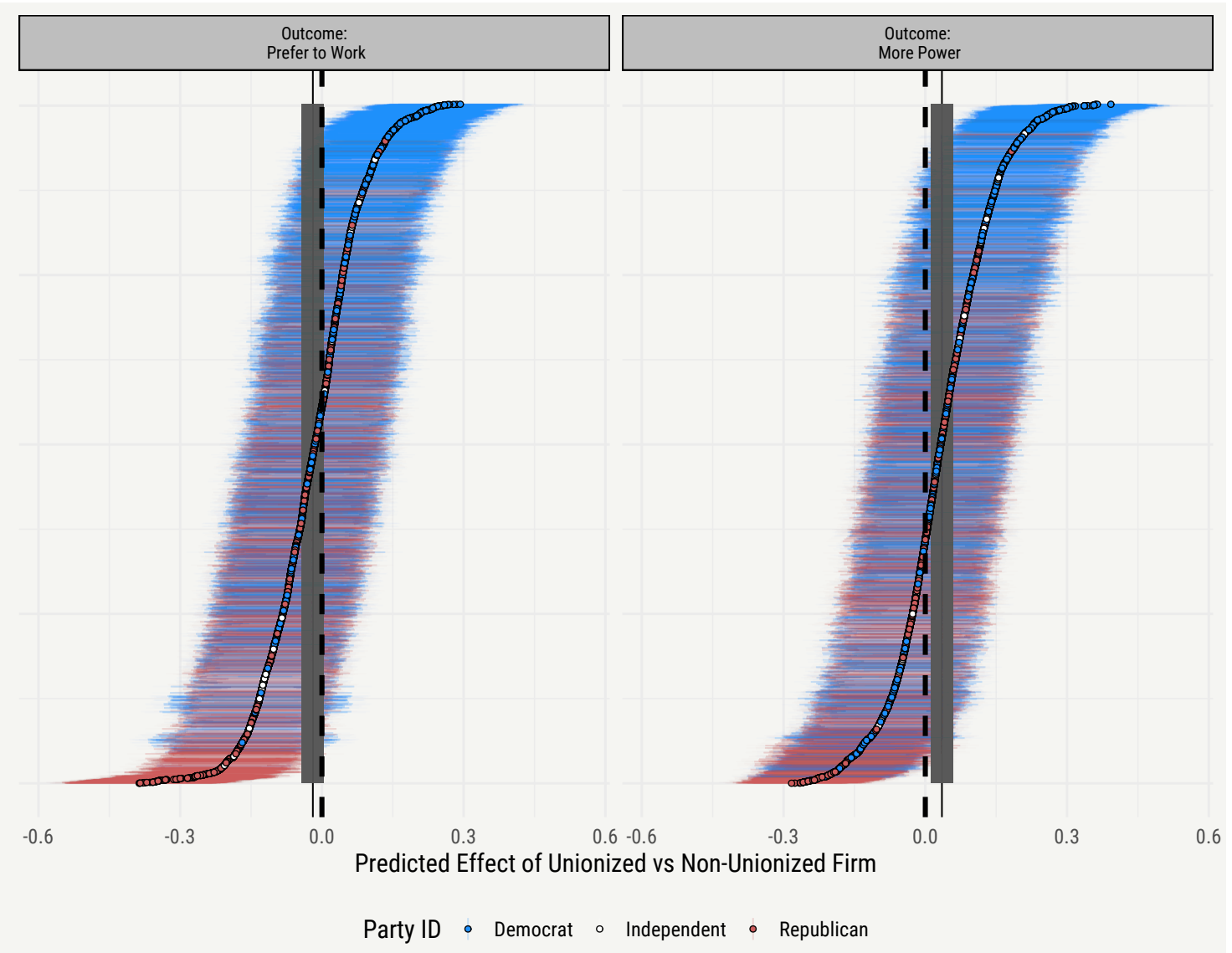

Notes: Estimates for the treatment effect for each trial where the comparison is between union vs non-union workplaces are ranked by magnitude and generated via causal forests. The thin vertical line represent the estimated causal effect of each treatment with the vertical shaded regions representing the $95 \%$ confidence interval. The horizontal shaded regions represent $95 \%$ confidence intervals of individual level treatment effect estimates.

having more power at work.

\section{Americans Today are Slightly Less Likely to Prefer Union Shops}

Thus far, we have explored and found consistent evidence that Americans prefer to work at more democratic firms and that they are not yet polarized on all policy proposals. An alternative (though not necessarily a substitute) form of empowering workers has historically been through unions. Do Americans also prefer to work at union shops? Our evidence based on the AMCE of unionization for work preference and power demonstrate clear evidence of polarization. Americans have a slight preference away from working at union shops $\left(C I_{95}=[-4 \mathrm{pp}, 0 \mathrm{pp}]\right)$ despite slightly recognizing that unions would provide them more power $\left(C I_{95}=[1 \mathrm{pp}, 6 \mathrm{pp}]\right)$. We note that these effects, again, likely provide lower bounds for the "true" union preference effect since we also manipulate many of the benefits that unions 
would bring to the workplace with respect to workers. Thus, we caution against interpreting these results as indicating that unions are not viable forms of labor organizations (HertelFernandez, Kimball, and Kochan 2019).

Another reason why we estimate small or even negative effects could be because Americans writ large have lost their faith in unions as an important part of the workplace. We provide evidence that this is likely not the case. These AMCEs, while substantively much lower than the AMCEs associated with workplace democracy proposals, mask a great deal of heterogeneity. The results shown in Figure 8 demonstrate that Democrats want to work at union shops and that they believe that union shops would provide them with more power while Republicans believe the reverse nearly symmetrically. Our results suggest that the partisan polarization around unions relative to other workplace democracy proposals might hinder the mass adoption of labor unions relative to the policies explored in this article.

\section{CONCLUSION}

If Americans overwhelmingly value democracy in the political sphere, do they not value it when it comes to the workplace-the space where most Americans spend most of their time? Using a conjoint experimental design, we show that the answer is that Americans actually do want economic democratization likely because they also intrinsically value having more power over their economic lives. In economic terms, workplace democracy proposals such as co-determination, ESOPs, and management elections are valued as equivalent to $\$ 70,000$ increase in salary when it comes to where Americans prefer to work. ${ }^{18}$ Unpacking why Americans prefer to work at democratic firms, our design allows us to show that Americans intrinsically value having more power at their workplace and that this feature helps to link workplace democracy to public preferences. Though we find little evidence that Americans are polarized on this issue as it relates to ESOPs and management elections, we do find some evidence of polarization where Republicans do not want to work at firms with co-determination (despite recognizing that they would have more power) suggesting the potential for partisan polarization to creep into support for workplace democracy.

We do recognize some important limitations of the experimental design presented. The most important of which is whether the results from the conjoint experiment actually map back onto "real world" behavior. While our evidence provides evidence of a descriptive nature

\footnotetext{
${ }^{18}$ Given the artificial nature of the survey, this is likely an upper bound. Though the labor supply elasticity is in line with existing evidence from behavioral field experiments Dube et al. (2020).
} 
that Americans do have a latent preference for workplace democracy, many other features of the actual job search process might prevent the realization of these latent preferences. Though conjoint studies have been shown to replicate "real world" behavior (Hainmueller, Hangartner, and Yamamoto 2015), we do not observe job search behavior as it relates to workplace democracy in equilibrium. Having established that there is an intrinsic value to workplace democracy above and beyond economic benefits that individuals might infer from simple field experiments that are only able to reasonably manipulate a few features, we recommend the use of field experiment techniques for future work to detect whether such preferences can be found in the wild.

Our results provide progress on an important puzzle in American political economy-why we don't observe more democratic firms. We show that this is not because Americans don't want to work at these types of firms. In fact, we show evidence that there is a economically meaningful preferences for these firms even when holding constant many economic benefits of workplace democratization. Thus, our results imply that other features of the political economy must be at play instead. These features could be as a result of a lack of supply of firms as a result of discrimination in financial markets or the historical political repression of groups advocating for workplace democracy (Gourevitch 2014). Future work, then, should explore what other pieces of this puzzle are missing since it cannot be explained by the lack of a mass preference for workplace democratization.

This article also raises a potential tension between preferences over labor unions and more co-operative forms of worker-management relations. ${ }^{19}$ Though in a recent working paper, Hertel-Fernandez, Kimball, and Kochan (2019) find that workers tend to prefer unions whose key benefits include collective bargaining strength, they also show that workers have a preference for union organizations that are currently unavailable under U.S. labor law. Within this context, we also find that after taking into account many of the benefits that unions would provide such as increased salaries and better benefits/working conditions, Americans do not have a preference for labor unions. At the same time, we show that Americans' support for co-operative forms of firm governance maintain support above and beyond pure material benefits. In era of historically low private sector union density, our results suggest that labor organizations might benefit from advocating for these more co-operative oriented changes to firm governance. ${ }^{20}$ As recently as 2014, the United Auto Workers campaigned on German-

\footnotetext{
${ }^{19}$ We would like to thank Paul Frymer for pushing us on this specific point.

${ }^{20}$ We want to emphasize that we are not suggesting that workplace democracy substitutes for unions. Instead, unions may benefit by raising the salience of workplace democracy.
} 
style workplace democracy in a Volkswagen plant in Tennessee. ${ }^{21}$ Although they lost that fight, our results suggests that one potential path to reinvigorate labor unions could be to advocate for workplace democracy emphasizing that in addition to material benefits, workplace democracy could provide workers power to prevent abuse by their bosses (Wright 2010). Given the current contours of American labor law, union participation in the project of economic democratization is essential.

Finally, this project also helps to open the door for further work that examines the political economy of corporate governance. For instance, an open question from our work is that if Americans do prefer economic democracy, where do these preferences come from? Why are some individuals more likely to prefer economic democracy than others? To what degree are reforms leading to more economic democracy compatible with labor union organizing? These are of course just a few of the many questions that we hope this article will help to reinvigorate.

\footnotetext{
${ }^{21}$ See here
} 


\section{References}

Abramson, Scott F., Korhan Kocak, and Asya Magazzinik. 2020. "What Do We Learn About Voter Preferences From Conjoint Experiments?” Working Paper.

Abramson, Scott F., et al. 2020. "Improving Preference Elicitation in Conjoint Designs using Machine Learning for Heterogeneous Effects." Working Paper.

Acemoglu, Daron, and Alexander Wolitzky. 2011. “The Economics of Labor Coercion.” Econometrica 79 (2): 555-600.

Acharya, Avidit, Matthew Blackwell, and Maya Sen. 2016. "Explaining Causal Findings Without Bias: Detecting and Assessing Direct Effects." American Political Science Review 110 (3): 512-529.

Ahler, Douglas J., and Gaurav Sood. 2018. “The Parties in Our Heads: Misperceptions about Party Composition and Their Consequences." Journal of Politics 80 (3): 964-981.

Alchian, Armen A., and Harold Demsetz. 1972. "Production, Information Costs, and Economic Organization." American Economic Review 62 (5): 777-795.

Anderson, Elizabeth. 2017. Private Government: How Employers Rule Our Lives (and Why We Don't Talk about It). Princeton University Press.

Ashenfelter, Orley C., Henry Farber, and Michael R. Ransom. 2010. "Labor Market Monopsony." Journal of Labor Economics 28 (2): 203-210.

Athey, Susan, Julie Tibshirani, and Stefan Wager. 2020. "Generalized Random Forests." The Annals of Statistics 47 (2): 1148-1178.

Autor, David, et al. 2019. "The Fall of the Labor Share and the Rise of Superstar Firms." Quarterly Journal of Economics 135 (2): 645-709.

Azar, Jose, Ioana Marinescu, and Marshall Steinbaum. Forthcoming. "Labor Market Concentration." Journal of Human Resources. 
Azar, Jose, Martin C. Schmalz, and Isabel Tecu. 2018. “Anti-Competitive Effects of Common Ownership." Journal of Finance 73 (4): 1513-1565.

Bachrach, Peter, and Morton S. Baratz. 1962. “Two Faces of Power.” American Political Science Review 56 (4): 947-952.

Balasubramanian, Natarajan, et al. Forthcoming. "Locked In? The Enforceability of Covenants Not to Compete and the Careers of High-Tech Workers." Journal of Human Resources.

Bansak, Kirk, et al. 2018. “The Number of Choice Tasks and Survey Satisficing in Conjoint Experiments." Political Analysis 26 (1): 112-119.

Baradaran, Mehrsa. 2017. The Color of Money: Black Banks and the Racial Wealth Gap. Harvard University Press.

Bebchuk, Lucian Arye. 2005. “The Case for Increasing Shareholder Power.” Harvard Law Review 118 (3): 2005.

Beglo, Miriam, and Luise Gorges. 2018. "On the Nature of Nuture: The Malleability of Gender Differences in Work Preferences." Journal of Economic Behavior and Organization 151:1941.

Benmelech, Efraim, Nittai Bergman, and Hyunseob Kim. 2018. "Strong Employers and Weak Employees: How Does Employer Concentration Affect Wages?” NBER Working Paper No. 24307.

Berle, Adolf, and Gardiner Means. 1932. The Modern Corporation and Private Property. MacMillan.

Blasi, Joseph R., Richard B. Freeman, and Douglas L. Kruse. 2014. The Citizen's Share: Reducing Inequality in the 21st Century. Yale University Press.

Braun, Benjamin. “American Asset Manager Capitalism.” Working Paper.

Chwe, Michael Suk-Young. 1990. "Why Were Workers Whipped? Pain in a Principal-Agent Model." Economic Journal: 1109-1121.

Ciepley, David. 2013. "Beyond Public and Private: Toward a Political Theory of the Corporation." American Political Science Review 107 (1): 139-158.

— . 2017. "Is the U.S. Government a Corporation? The Corporate Origins of Modern Constitutionalism." American Political Science Review 111 (2): 418-435. 
Cioffi, John W., and Martin Hopner. 2006. “The Political Paradox of Finance Capitalism: Interests, Preferences, and Center-Left Party Politics in Corporate Governance Reform.” Politics \& Society 34 (4): 463-502.

Coase, R.H. 1937. “The Nature of the Firm.” Economica 4 (16): 386-405.

Combahee River Collective. 1977. The Combahee River Collective Statement.

Dafoe, Allan, Baobao Zhang, and Devin Caughey. 2018. "Information Equivalance in Survey Experiments." Political Analysis 26 (4): 399-416.

Dahl, Robert A. 1986. A Preface to Economic Democracy. University of California Press.

— . 2001. "A Right to Workplace Democracy? Response to Robert Mayer." Review of Politics 63 (2): 249-253.

- . 2005. Who Governs? Democracy and Power in an American City. Yale University Press.

Davis, Gerarld F., and Henrich R. Greve. 1997. "Corporate Elite Networks and Governance Changes in the 1980s." American Journal of Sociology 103 (1): 1-37.

Davis, Gerarld F., and Tracy A. Thompson. 1994. "A Social Movement Perspective on Corporate Control." Administrative Science Quarterly 39 (1): 141-173.

Dippel, Christian. 2014. "Forced Coexistence and Economic Development: Evidence from Native America Reservations." Econometrica 82 (6): 2131-2165.

Du Bois, W.E.B. 2014. Black Reconstruction in America (The Oxford W. E. B. Du Bois): An Essay Toward a History of the Part Which Black Folk Played in the Attempt to Reconstruct Democracy in America, 1860-1880. Oxford University Press.

Dube, Arindrajit, et al. 2020. "Monopsony in Online Labor Markets." American Economic Review: Insights 2 (1): 33-46.

Ederer, Florian, Colleen Cunningham, and Song Ma. Forthcoming. "Killer Acquisitions.” Journal of Political Economy.

Ehrenreich, John, and Barbara Ehrenreich. 1979. Between Labor and Capital. South End Press.

Eidlin, Barry, and Micah Uetricht. 2018. “The Problem of Workplace Democracy.” New Labor Forum 27 (1): 70-79.

Eriksson, Tor, and Nicolai Kristensen. 2014. "Wages or Fringes? Some Evidence on Trade-Offs and Sorting." Journal of Labor Economics 32 (4): 899-928.

Fligstein, Neil. 1993. The Transformation of Corporate Control. Harvard University Press. 
Flory, Jeffrey A., Andreas Leibbrandt, and John A. List. 2015. "Do Competitive Workplaces Deter Female Workers? A Large-Scale Natural Field Experiment on Job-Entry Decisions.” Review of Economic Studies 82 (1): 122-155.

Freeman, Richard B., and Joel Rogers. 2006. What Workers Want. Russell Sage Foundation.

Frymer, Paul. 2005. "Racism Revised: Courts, Labor Law, and the Institutional Construction of Racial Animus." American Political Science Review 99 (3): 373-387.

Gilmore, Ruth Wilson. 2007. Golden Gulag: Prisons, Surplus, Crisis, and Opposition in Globalizing California. University of California Press.

Goldstein, Adam. 2012. "Revenge of the Managers: Labor Cost-Cutting and the Paradoxical Resurgence of Managerialism in the Shareholder Value Era, 1984 to 2001." American Sociological Review 77 (2): 268-294.

Gompers, Paul, Joy Ishii, and Andrew Metrick. 2003. "Corporate Governance and Equity Prices." Quarterly Journal of Economics 118 (1): 107-156.

Gourevitch, Alex. 2014. From Slavery to the Cooperative Commonwealth: Labor and Republican Liberty in the Nineteenth Century. Cambridge University Press.

— . 2018. “The Right to Strike: A Radical View." American Political Science Review 112 (4): 905-917.

Grossman, Sanford J., and Oliver D. Hart. 1986. "The Costs and Benefits of Ownership: A Theory of Vertical and Lateral Integration." Journal of Political Economy 94 (4): 691-719.

Hacker, Jacob S. 2004. "Privatizing Risk without Privatizing the Welfare State: The Hidden Politics of Social Policy Retrenchment in the United States." American Political Science Review 98 (2): 243-260.

Hainmueller, Jens, Dominik Hangartner, and Teppei Yamamoto. 2015. "Validating Vignette and Conjoint Survey Experiments against Real-World Behavior." Proceedings of the National Academy of Science 112 (8): 2395-2400.

Hainmueller, Jens, and Daniel J Hopkins. 2014. “The Hidden American Immigration Consensus: A Conjoint Analysis of Attitudes toward Immigrants." American Journal of Political Science 59 (3): 529-548.

Hainmueller, Jens, Daniel J. Hopkins, and Teppei Yamamoto. 2014. "Causal Inference in Conjoint Analysis: Understanding Multidimensional Choices via Stated Preference Experiments." Political Analysis 22 (1): 1-30. 
Hall, Peter A., and David Soskice. 2001. Varieties of Capitalism: The Institutional Foundations of Comparative Advantage. Oxford University Press.

Hart, Oliver D., and John Moore. 1990. "Property Rights and the Nature of the Firm.” Journal of Political Economy 98 (6): 1119-1158.

Hertel-Fernandez, Alexander. 2018. Politics at Work: How Companies Turn Their Workers into Lobbyists. Oxford University Press.

- . 2019. State Capture: How Conservative Activists, Big Businesses, and Wealthy Donors Reshaped the American States - and the Nation. Oxford University Press.

Hertel-Fernandez, Alexander, William Kimball, and Thomas Kochan. 2019. "How U.S. Workers Think About Workplace Democracy: The Structure of Individual Worker Preferences for Labor Representation.” Washington Center for Economic Growth Working Paper Series.

Hirschman, Albert O. 1972. Exit, Voice, and Loyalty: Response to Decline in Firms, Organizations, and States. Harvard University Press.

Huber, Gregory, and Neil Malhotra. 2016. "Political Homophily in Social Relationships: Evidence form Online Dating Behavior." Journal of Politics 79 (1): 269-283.

Iyengar, Shanto, and Sean J. Westwood. 2015. "Fear and Loathing across Party Lines: New Evidence on Group Polarization.” American Journal of Political Science 59 (3): 690-707.

Jager, Simon, Benjamin Schoefer, and Jorg Heining. 2019. “Labor in the Boardroom.” Working Paper.

James, C.L.R. 1989. The Black Jacobins: Toussaint L'Ouverture and the San Domingo Revolution. Vintage Books.

Jensen, Michael C., and William H. Meckling. 1976. “Theory of the Firm: Managerial Behavior, Agency Costs, and Ownership Structure." Journal of Financial Economics 3 (4): 305-360.

Kang, David L., and Aage B. Sorenson. 1999. "Ownership Organization and Firm Performance." Annual Review of Sociology 25 (121-144).

Kochan, Thomas A., et al. 2019. "Worker Voice in America: Is There a Gap between What Workers Expect and What They Experience?" Industrial and Labor Relations Review 72 (1): 3-38.

Kostiuk, Peter F. 1990. “Compensating Differentials for Shift Work.” Journal of Political Economy 98 (5): 1054-1075. 
Krueger, Alan B., and Orley Ashenfelter. 2018. “Theory and Evidence on Employer Collusion in the Franchise Sector.” NBER Working Paper No. 24831.

La Porta, Rafael, Florencio Lopez-de-Silanes, and Andrei Shleifer. 1999. “Corporate Ownership Around the World." Journal of Finance 54 (2): 471-517.

La Porta, Rafael, et al. 2000. "Investor Protection and Corporate Governance." Journal of Financial Economics 58 (1): 3-27.

Leong, Nancy. 2013. “Racial Capitalism.” Harvard Law Review 126 (8): 2153-2225.

Li, Zhao. 2018. "How Internal Constraints Shape Interest Group Activities: Evidence from Access-Seeking PACs.” American Political Science Review 112 (4): 792-808.

Lipsitz, Michael, and Evan Starr. Forthcoming. "Low-Wage Workers and the Enforceability of Non-Compete Agreements.” Management Science.

Lovett, Frank, and Philip Pettit. 2009. "Neorepublicanism: A Normative and Institutional Research Program." Annual Review of Political Science 12:11-29.

Lukes, Steven. 1974. Power: A Radical View. Macmillan.

Manning, Alan. 2003. Monopsony in Motion: Imperfect Competition in Labor Markets. Princeton University Press.

Marx, Matt. 2011. “The Firm Strikes Back: Non-compete Agreements and the Mobility of Technical Professionals." American Sociological Review 76 (5): 695-712.

Mas, Alexandre, and Amanda Pallais. 2017. "Valuing Alternative Work Arrangements." American Economic Review 107 (12): 3722-3759.

Mason, Lilliana. 2018. Uncivil Agreement: How Politics Became our Identity. University of Chicago Press.

Mayer, Robert. 2001. "Robert Dahl and the Right to Workplace Democracy." Review of Politics 63 (2): 221-247.

Meixell, Brady, and Ross Eisenbrey. 2014. An Epidemic of Wage Theft Is Costing Workers Hundreds of Millions of Dollars a Year. Tech. rep. Economic Policy Institute.

Naidu, Suresh. 2010. "Recruitment Restrictions and Labor Markets: Evidence from the Postbellum U.S. South.” Journal of Labor Economics 28 (2): 413-445.

Pagano, Marco, and Paolo F. Volpin. 2005. "The Political Economy of Corporate Governance." American Economic Review 95 (4): 1005-1030. 
Pettit, Philip. 1999. Republicanism: A Thoery of Freedom and Government. Oxford University Press.

Przeworski, Adam, and Michael Wallerstein. 1988. "Structural Dependence of the State on Capital." American Political Science Review 82 (1): 11-29.

Rajan, Raghuram G., and Luigi Zingales. 1998. "Power in a Theory of the Firm." Quarterly Journal of Economics 113 (2): 387-432.

— . 2002. "The Firm as a Dedicated Hierarchy: A Theory of the Origins and Growth of Firms." Quarterly Journal of Economics 116 (3): 805-851.

Robinson, Cedric J. 2000. Black Marxism: The Making of the Black Radical Tradition. University of North Carolina Press.

Starr, Evan, J.J. Prescott, and Norman Bishara. Forthcoming. "The Behavioral Effects of (Unenforceable) Contracts." Journal of Law, Economics, and Organization.

Taylor, Keeanga-Yamahtta. 2019. Race for Profit: How Banks and the Real Estate Industry Undermined Black Homeownership. University of North Carolina Press.

Vogel, David. 1989. Fluctuating Fortunes: The Political Power of Business in America. Beard Books.

Wiswall, Matthew, and Basit Zafar. 2018. "Preference for the Workplace, Investment in Human Capital, and Gender." Quarterly Journal of Economics 133 (1): 457-507.

Wright, Erik Olin. 2000. “Class, Exploitation, and Economic Rents: Reflections on Sorensen's 'Sounder Basis"' American Journal of Sociology 105 (6): 1559-1571.

— . 2010. Envisioning Real Utopias. Verso Books. 
Online Appendix 


\section{Contents}

Contents $\quad$ A0

Sample Descriptives . . . . . . . . . . . . . . . . A A1

Robustness to Weighting . . . . . . . . . . . . . . . . A A2

Additional Results . . . . . . . . . . . . . . . . A3 


\section{SAMPLE DESCRIPTIVES}

Table A1-1: Descriptive Statistics

\begin{tabular}{lccc}
\hline \hline Statistic & Mean & St. Dev. & $\mathrm{N}$ \\
\hline Male & 0.440 & 0.497 & 1,002 \\
Female & 0.560 & 0.497 & 1,002 \\
4-year college & 0.228 & 0.419 & 1,002 \\
Post-grad & 0.142 & 0.349 & 1,002 \\
High school graduate & 0.227 & 0.419 & 1,002 \\
2-year college & 0.130 & 0.336 & 1,002 \\
Some college & 0.250 & 0.433 & 1,002 \\
No HS & 0.025 & 0.156 & 1,002 \\
White & 0.762 & 0.426 & 1,002 \\
Hispanic & 0.074 & 0.262 & 1,002 \\
Mixed & 0.008 & 0.089 & 1,002 \\
Black & 0.103 & 0.304 & 1,002 \\
Native American & 0.010 & 0.099 & 1,002 \\
Asian & 0.028 & 0.165 & 1,002 \\
Other & 0.023 & 0.150 & 1,002 \\
Retired & 0.273 & 0.446 & 1,002 \\
Part-time & 0.089 & 0.285 & 1,002 \\
Unemployed & 0.060 & 0.237 & 1,002 \\
Full-time & 0.353 & 0.478 & 1,002 \\
Permanently disabled & 0.086 & 0.280 & 1,002 \\
Homemaker & 0.056 & 0.230 & 1,002 \\
Temporarily laid off & 0.039 & 0.194 & 1,002 \\
Student & 0.021 & 0.143 & 1,002 \\
Not a union member & 0.927 & 0.260 & 1,002 \\
Union member & 0.073 & 0.260 & 1,002 \\
\hline
\end{tabular}




\section{ROBUSTNESS TO WEIGHTING}

Figure A1-1: Main effects on all outcomes

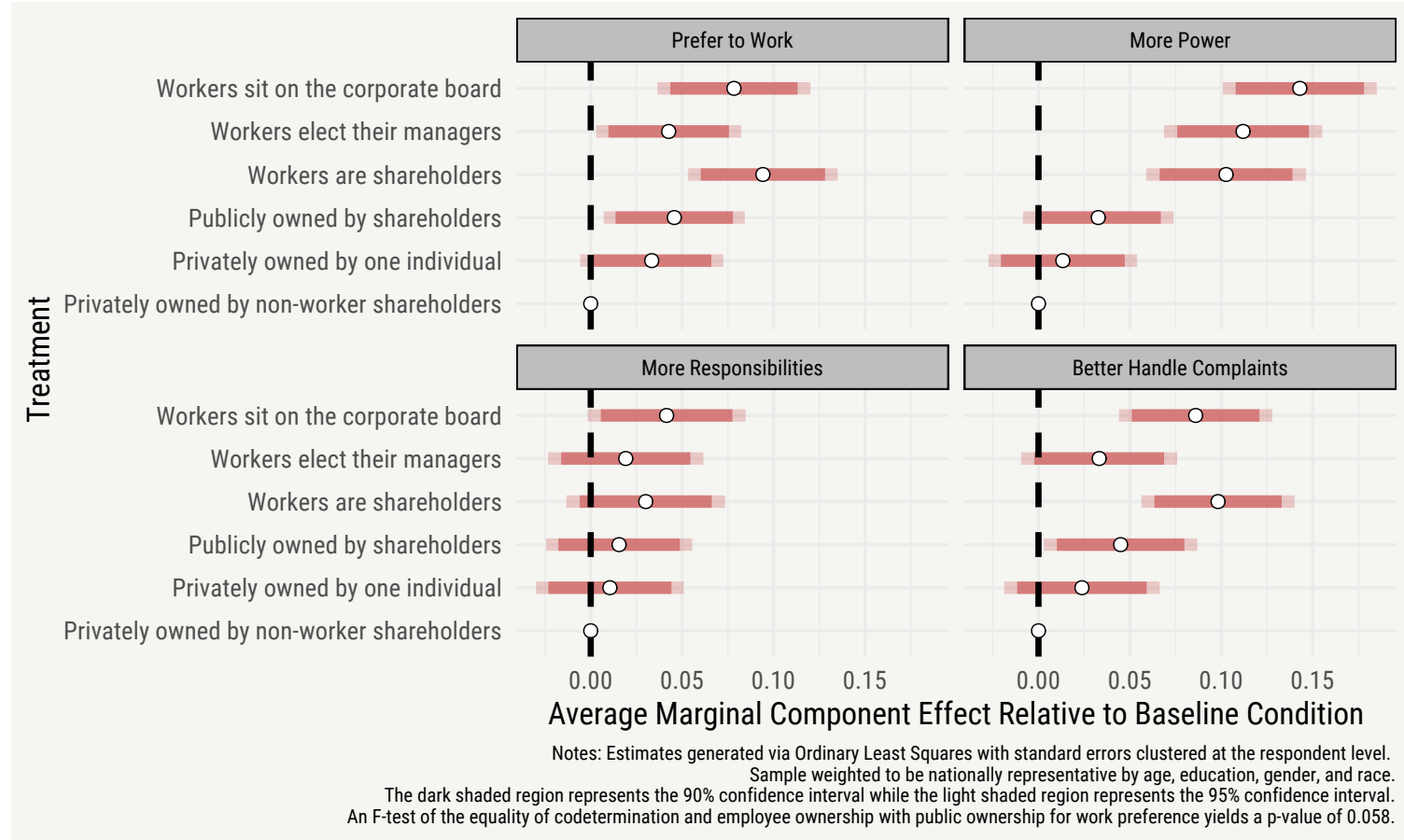


ADDITIONAL RESULTS

Figure A1-2: Main effects on all outcomes

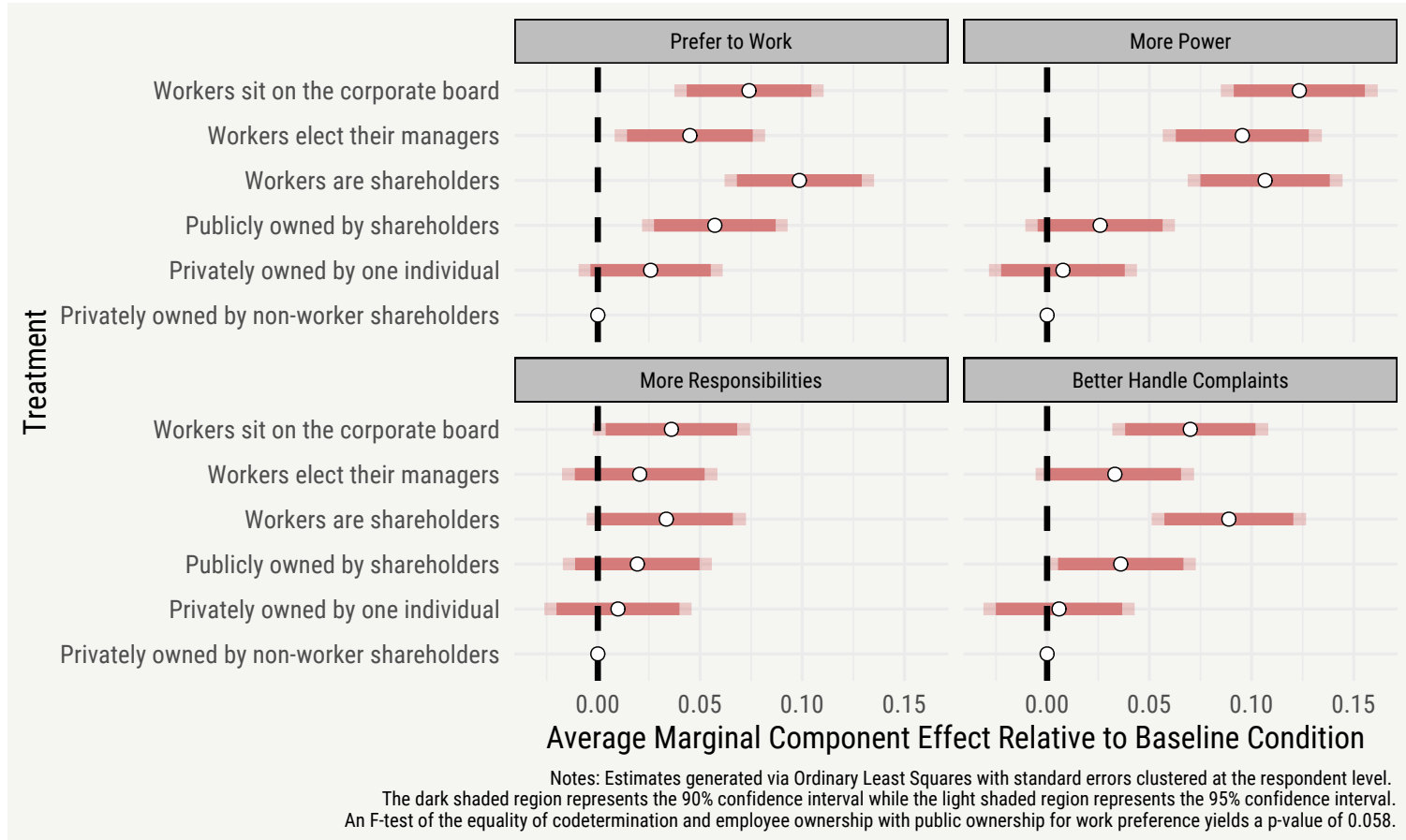


Figure A1-3: Linearity of income effect

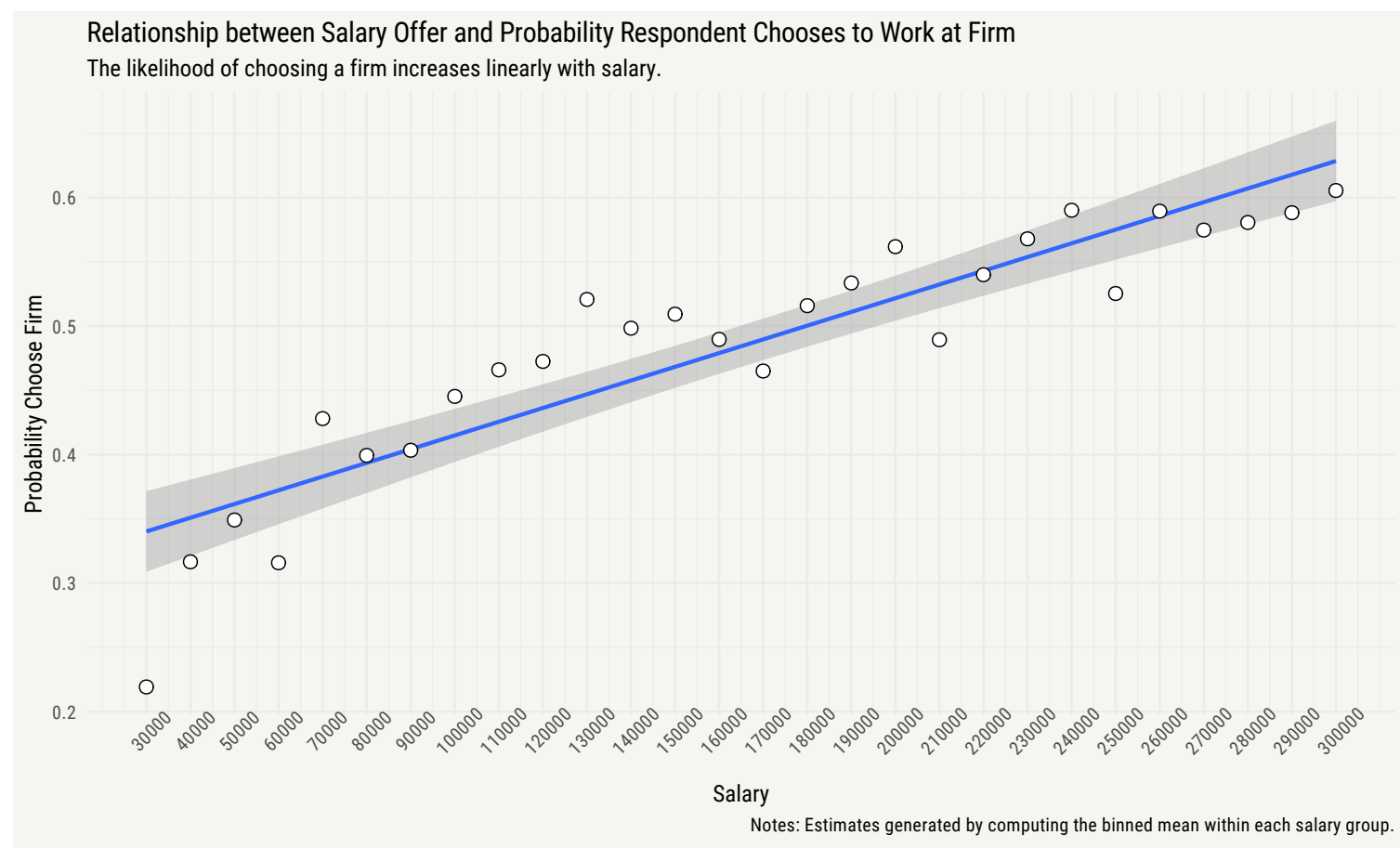




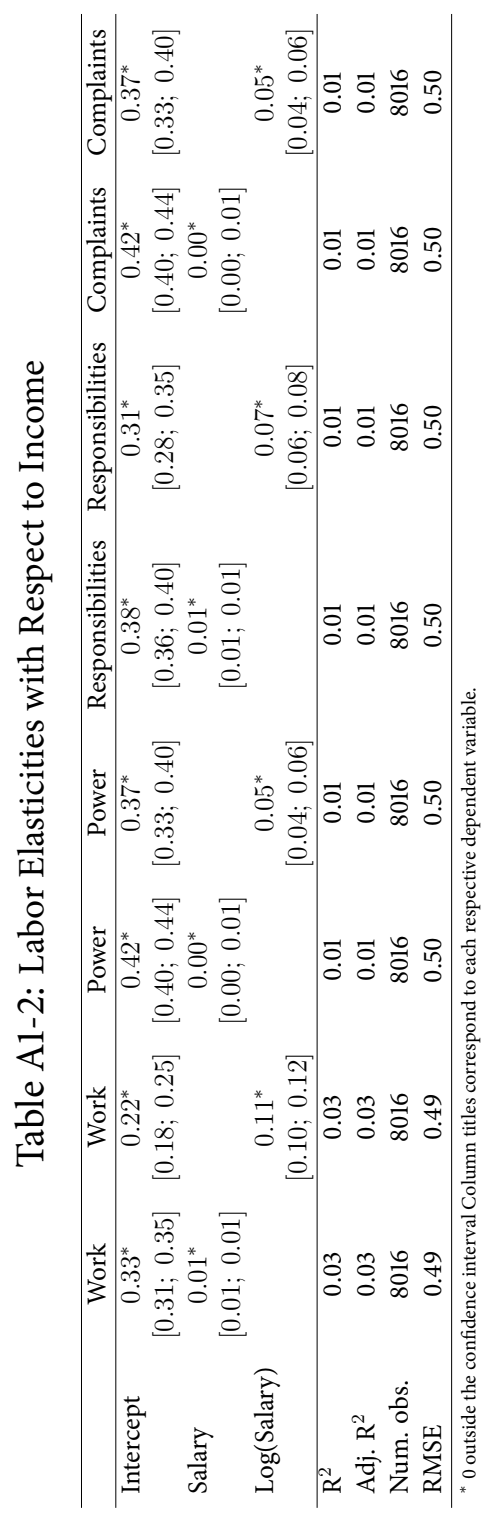


Figure A1-4: Assessing the Interaction Effect Assumption for Causal Mediation Estimation

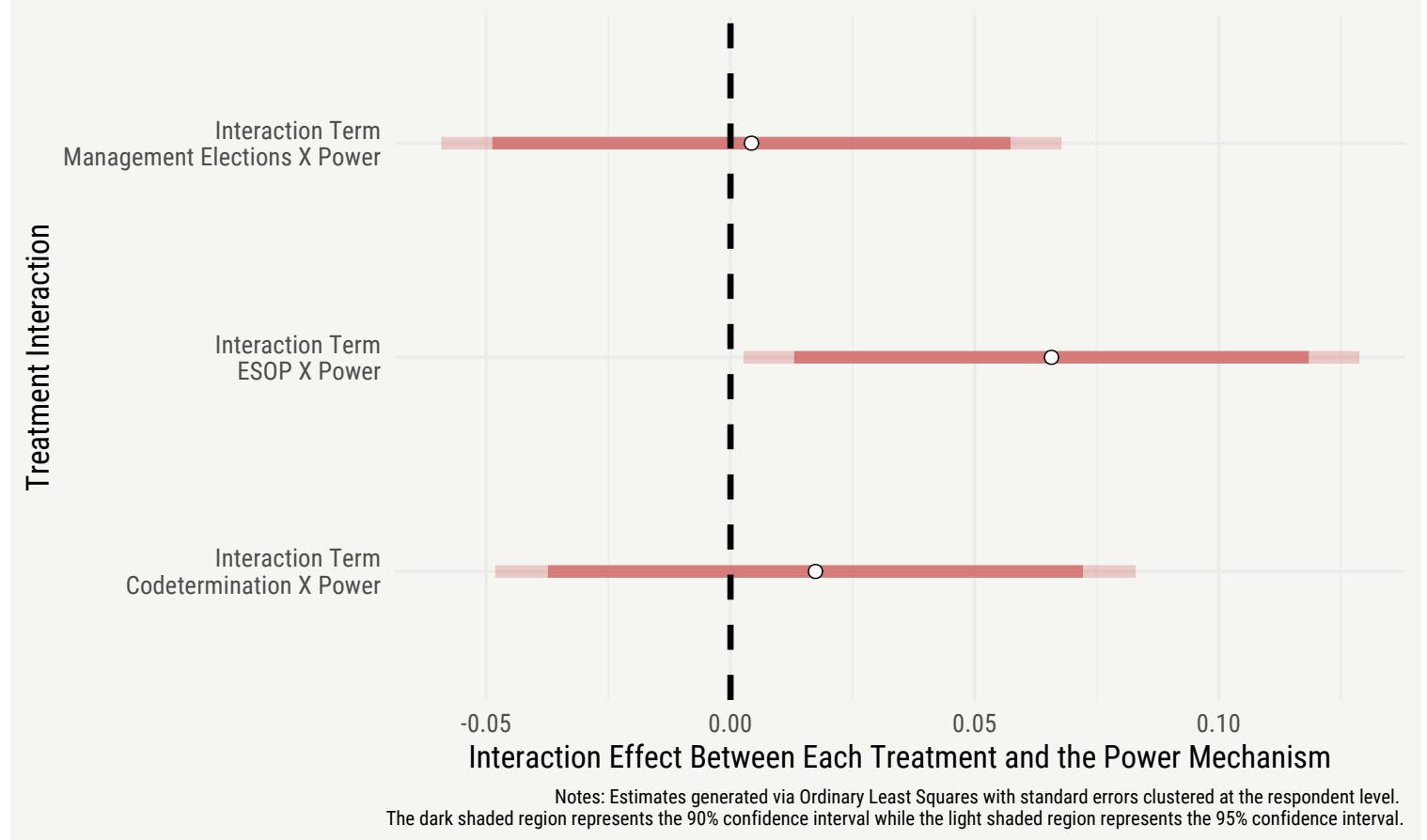


Figure A1-5: Sensitivity Analysis of Sequential Unconfoundedness Assumption Needed for Mediation Analysis

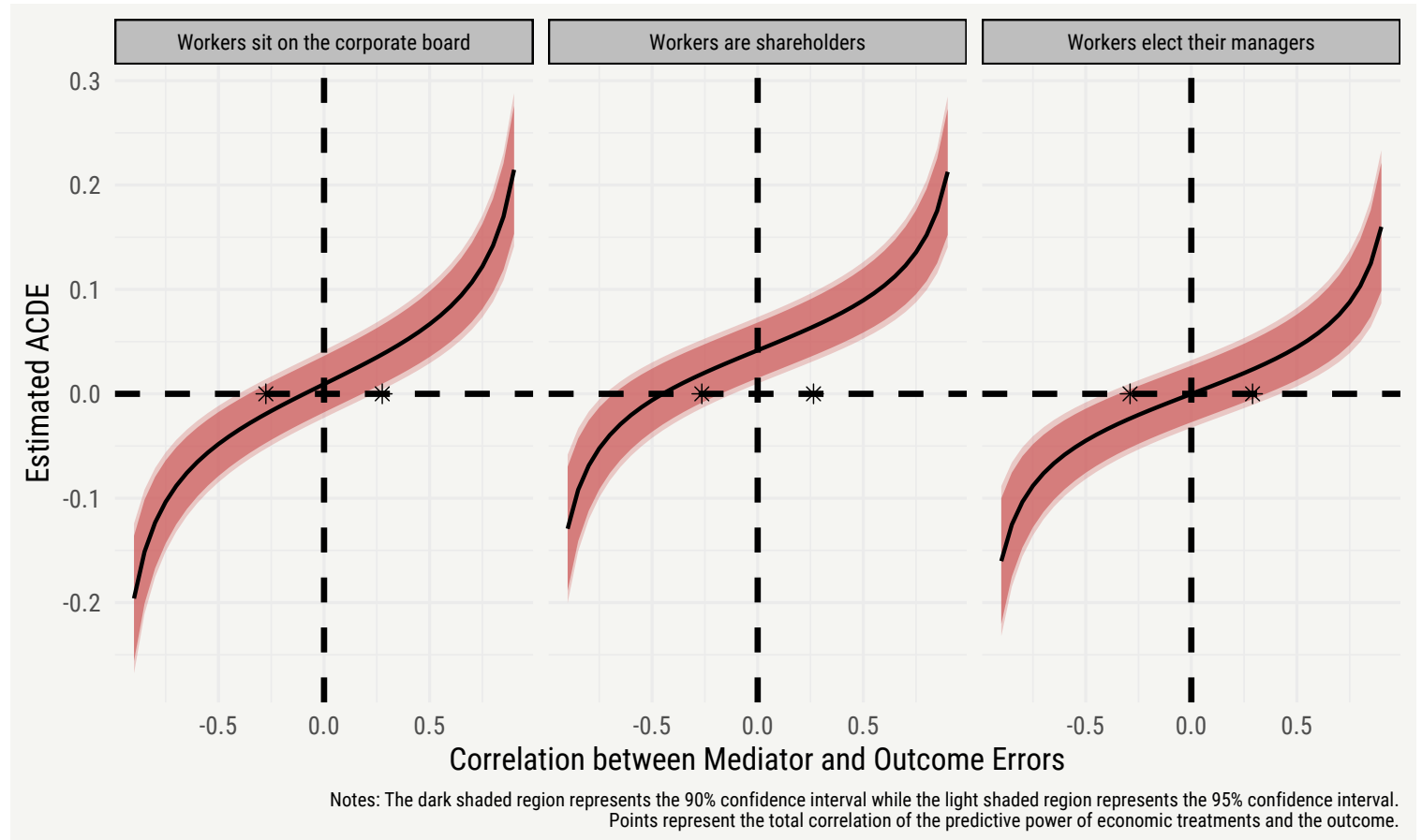


Figure A1-6: Effect of different workplace regimes.

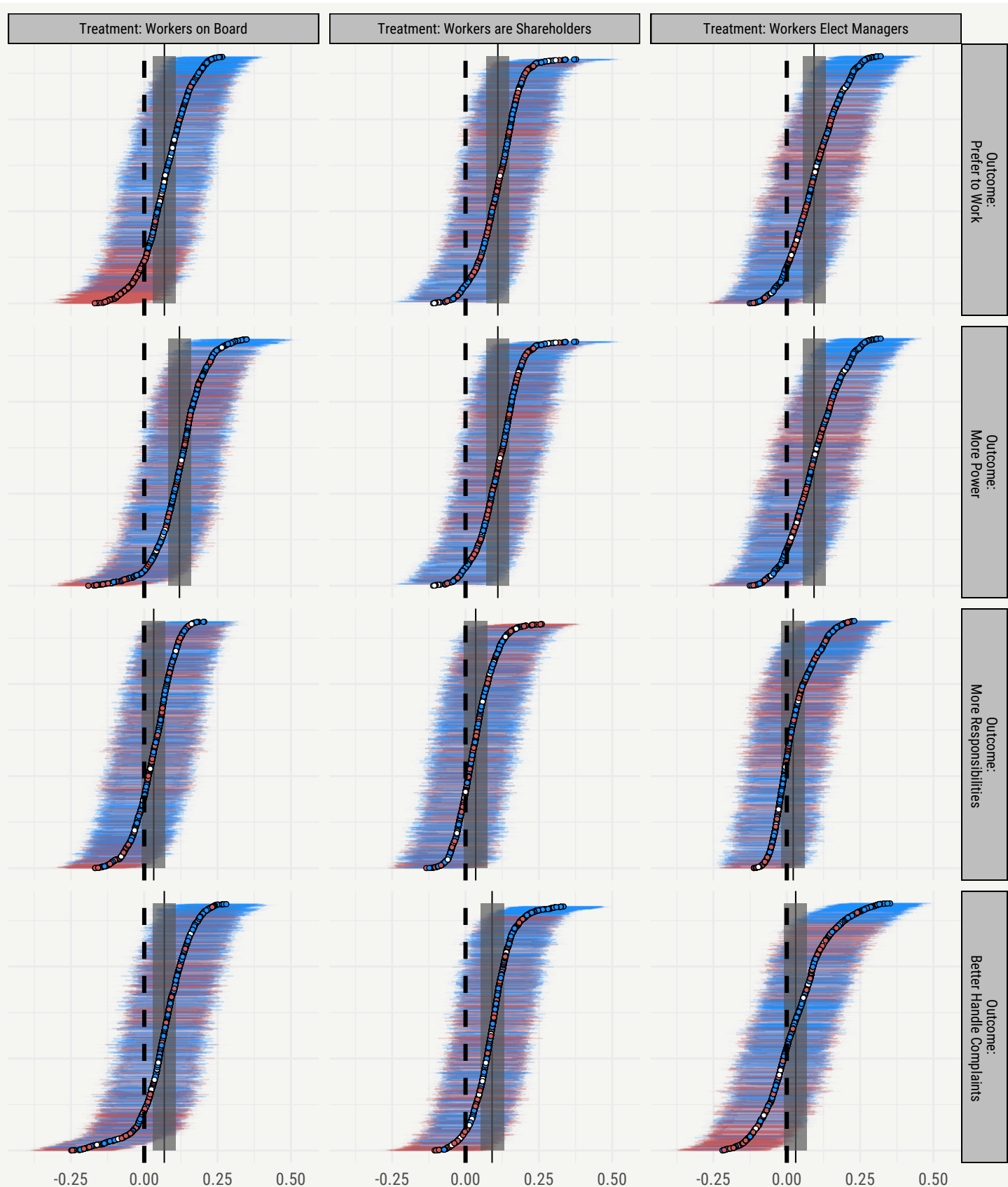

Predicted Effect of Treatment vs Private Ownership by Non-Worker Shareholders

Party ID • Democrat $\circ$ Independent $\bullet$ Republican

Notes: Estimates for the treatment effect for each trial where the comparison is against private ownership by non-worker shareholders are ranked by magnitude and generated via causal forests. The thin vertical line represent the estimated causal effect of each treatment with the vertical shaded regions representing the $95 \%$ confidence interval. The horizontal shaded regions represent $95 \%$ confidence intervals of individual level treatment effect estimates. 
Figure A1-7: Effect of unionization.
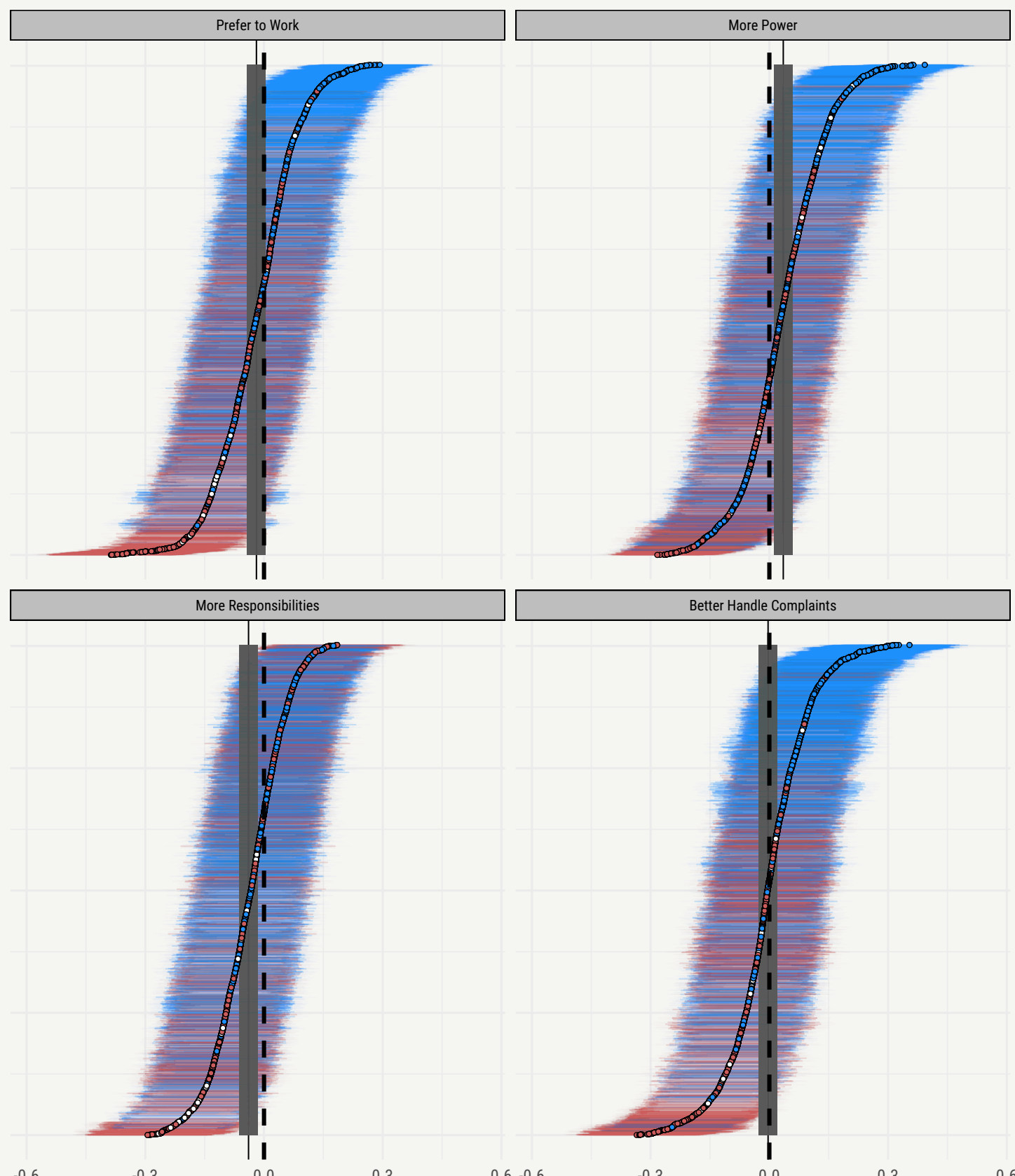

$-0.6$

$-0.3$

0.0

Predicted Effect
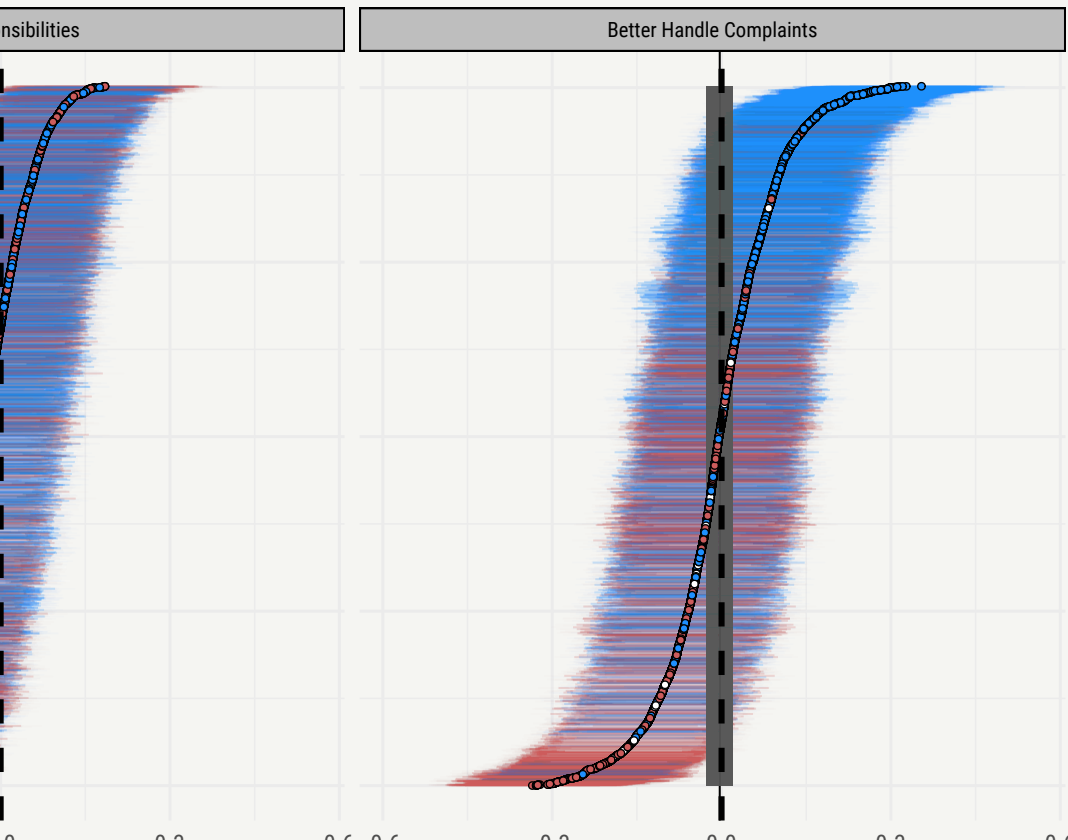

$0.6-0.6$

$-0.3$

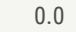

Party ID • Democrat 。 Independent ○ Republican

Notes: Estimates for the treatment effect for each trial where the comparison is between union vs non-union workplaces are ranked by magnitude and generated via causal forests. The thin vertical line represent the estimated causal effect of each treatment with the vertical shaded regions representing the $95 \%$ confidence interval. The horizontal shaded regions represent $95 \%$ confidence intervals of individual level treatment effect estimates. 